\title{
THE IMPACT OF THE CHANGING TECHNOLOGY OF MOTOR VEHICLES ON ROAD TAX REVENUE
}

\author{
ALEXANDER ROBERT ('LEX') FULLARTON*
}

\begin{abstract}
This paper considers the impact on road tax revenue of changes in the technology of motor vehicles. As the drive trains of motor vehicles are transformed from internal combustion engines to electric motors, their energy sources may transition significantly from taxable fossil fuel to non-taxable renewable energy. Revenue from motor vehicle fuel excises levied on petroleum products and allocated to the construction and maintenance of Australia's roadways will decrease accordingly. Therefore, to continue to fund the road transport infrastructure, governments will be obliged to change their focus about how road tax revenue is raised. This paper considers the current number of electric vehicles (EVs) on Australian roads and attempts to predict the future uptake of EVs by road users up to the year 2035. It looks at the likely impact of reduced road tax revenue from motor vehicle fuel excises on future contributions by the Australian government for the construction and maintenance of Australian roadways. To that end, the paper examines data published by the Australian Bureau of Statistics (ABS) and statistics from the Australian Taxation Office (ATO). It also refers to sales data provided by motor vehicle manufacturers. It then compares the results of those examinations with data from a case study of a plug-in hybrid electric vehicle (PHEV) owned and operated by a solar project in rural Western Australia. The paper concludes that future revenue from fuel excises may decrease as a consequence of the introduction of EVs. However, as there has not been an official link between road tax revenue and road construction and maintenance expenditures since 1959, a reduction in road tax revenue will not necessarily affect funding for the construction and maintenance of Australian roadways.
\end{abstract}

\section{INTRODUCTION}

Arguably, it is settled science that atmospheric pollution contributes significantly to humaninduced climate change. A major contributor to that pollution and a source of greenhouse gas

\footnotetext{
* PhD (Tax) (UNSW), M Com (tax) (Curtin), Adjunct Professor, Faculty of Business and Law, Curtin University, Lex.Fullarton@ curtin.edu.au. Lex Fullarton is a former provincial tax practitioner and is also a solar farmer as well as an accredited agent and solar pv installation designer with the Australian Clean Energy Regulator.
} 
emissions is the combustion of fossil fuels, ${ }^{1}$ and in particular, those emitted from the internal combustion engine. ${ }^{2}$

The efficient and reliable internal combustion engine has powered the world's motor vehicles for over 140 years. However, the atmospheric pollution produced by it has caused the world's population to seek alternative and cleaner energy systems for motorisation. ${ }^{3}$ Electrically powered vehicles, in particular those charged from non-polluting, renewable energy sources, can significantly reduce greenhouse gas emissions from the road transport sector. ${ }^{4}$ Electric vehicles are gaining considerable world-wide popularity with consumers and governments. It is inevitable that electric and electric hybrid vehicles will ultimately displace the current internal combustion-powered vehicles. It has been reported that some governments, such as Norway, France, the Netherlands and the UK, intend to place bans on internal combustion engine-powered vehicles as early as $2030 .^{5}$

In response, motor vehicle manufacturers are turning away from fossil-fuelled internal combustion engines to electric motors to reduce atmospheric pollution. New and existing motor vehicle manufacturers, such as Tesla, Mitsubishi and Nissan, have launched many new models and makes of very powerful electric vehicles. However, a consequence of the transition to electric vehicles is that road tax revenues, raised primarily from excises currently levied on fossil fuels consumed by motor vehicle users, will decrease.

Concerns have been raised in Australia that revenue from taxes on motor spirits, which has generally been applied to the development, construction and maintenance of the roadway network, will be significantly reduced.

In 2016, a newspaper article asserted that

Australians who drive Holden Commodores are paying three times as much tax for federal roads as those who own hybrid vehicles such as the Toyota Prius, sparking fears of a funding crisis that could keep every motorist in the slow lane for years. Wealthier Australians who can afford to buy hybrid and electric cars are starting to erode the $\$ 12$ billion in annual fuel excise that pays

1 Frederica P Perera, 'Multiple Threats to Child Health from Fossil Fuel Combustion: Impacts of Air Pollution and Climate Change' (2017) 125(2) Environmental Health Perspectives <https://ehp.niehs.nih.gov/ehp299/> at 16 February 2016.

2 Nikhil Sharma et al, 'Air Pollution and Control' in Avinash Kumar Agarwal and Ashok Pandey (eds) Energy, Environment and Sustainability (Springer, 2017) 3.

3 Roberto Álvarez Fernández , 'A More Realistic Approach to Electric Vehicle Contribution to Greenhouse Gas Emissions in the City’ (2018) 172 Journal of Cleaner Production <https://www.sciencedirect.com/science/article/pii/S0959652617324654> at 16 February 2016.

4 World Nuclear Association, Electricity and Cars (2017) <http://www.world-nuclear.org/informationlibrary/energy-and-the-environment/electricity-and-cars.aspx > at 19 October 2017.

$5 \quad$ Frederick Lambert, The Dutch Government Confirms Plan to Ban New Petrol and Diesel Cars by 2030 (Electrek, 2017) <https://electrek.co/2017/10/10/netherlands-dutch-ban-petrol-diesel-cars-2030-electriccars/> at 19 October 2017; Matt Pressman, 'Electric Car Incentives in Norway, UK, France, Germany, Netherlands, \& Belgium' (2017) CleanTechnica <https://cleantechnica.com/2017/09/02/electric-carincentives-norway-uk-france-germany-netherlands-belgium/> at 19 October 2017. 
for the nation's roads, forcing the federal government to look at new ways to raise cash for major projects. ${ }^{6}$

However, despite the assertion that the rising numbers of electric vehicles will have a significant negative impact on roadway expenditures, the nexus between fuel excises and expenditures on Australian roadway construction and maintenance is not as closely related as alleged. Revenue collected from road taxes has not been directly applied to the construction and maintenance of Australian roads for nearly 60 years. In 2000, a report to the Australian Parliament stated that

[p]etrol and diesel excises are levied primarily to raise revenue. A second reason is to recover from road users the costs they impose on society. And, historically, revenue from excise was at times hypothecated to fund expenditure on roads. Hypothecation is the earmarking of the revenue from a particular tax for spending on a particular purpose. ${ }^{7}$

The report also stated that

[w]ith the exceptions of road tolls and heavy vehicle road use charges, ${ }^{8}$ road users do not pay directly for their use of roads. In the absence of direct road use charges, petrol and diesel excises are a proxy for the cost of road use, in that the total amount of excise a user pays through fuel consumption is related to distance travelled and vehicle weight. ${ }^{9}$ But excises are an inefficient means of cost recovery in that the amount of excise a user pays does not vary directly with the social cost of using a specific road. ${ }^{10}$

This paper aims to evaluate the impact of decreasing government revenue from reduced fossil fuel consumption by the transport sector of the Australian economy caused by the introduction of electrically powered vehicles. Its primary purpose is to investigate the possible impact of electrically powered vehicles on the tax revenue currently raised from fuel excises levied on the owners of fossil-fuelled motor vehicles. It focuses on the likely impact on fuel excises in Australia.

First, the paper provides a brief history of Australian fuel excises and how they were initially hypothecated to the construction and maintenance of roadways. It then reviews the published literature to examine the previous research findings on the likely impact of the transition from internal combustion engines to electric vehicles on greenhouse gas emissions from the transport sector in Australia. That review is followed by the method adopted in this research. The research is conducted by an examination of government agency reports to provide likely projections of the uptake of electric vehicles in Australia and a comparative analysis for the

6 David Crowe, 'Electric Cars Blow Hole in Road-Building Petrol Tax Revenues' The Australian (Sydney), 16 August 2016.

$7 \quad$ Richard Webb, Petrol and Diesel Excises (Economics, Commerce and Industrial Relations Group, 2000) <http://www.aph.gov.au/About_Parliament/Parliamentary_Departments/Parliamentary_Library/pubs/rp/rp 0001/01RP06\#WhyisExciseLevied> at 16 July 2017.

8 For a discussion of these charges, see Richard Webb, 'Cost Recovery in Road and Rail Transport' (Research Paper No 28, Department of the Parliamentary Library, Parliament of Australia, 1999-2000).

9 The Australian Automobile Association advocates that the petrol excise be divided into a road user charge component and a general revenue component, with the former allocated to road investment. See Lauchlan McIntosh, 'Charging for Road Use' (CEDA Bulletin, October 1998) 61-2.

10 Webb, above $n 7$. 
fossil fuel consumption of internal combustion engine-driven motor vehicles with similar types of electric passenger vehicle makes and models. It uses a case study approach to compare that statistical analysis with the operations of an electric vehicle, used in a practical application over a 17-month period in north-western Australia.

Finally, it presents its conclusions and contributions to the literature, records the limitations of the research and suggests areas for further research. To provide the background and context, a brief history of Australia's fuel excise follows.

\section{A BRIEF HISTORY OF THE AUSTRALIAN FUEL EXCISE}

In 1959, the Commonwealth government removed the nexus between revenue raised from 'the collections from time to time of the duties of customs and duties of excise' ${ }^{11}$ and 'the construction, reconstruction, maintenance and repair of roads or on the purchase of roadmaking plant'. ${ }^{12}$ The Commonwealth Aid Roads Act 1959 (Cth) differed from its predecessors in that it provided for a tied financial grant ${ }^{13}$ of $£ 220000000$ over five years (1959-63). ${ }^{14}$ The 1959 legislation made no reference to the collection of customs or excise duties to fund those grants. Speeches made in support of ${ }^{15}$ and opposition to,${ }^{16}$ the Commonwealth Aid Roads Bill 1959 make it quite clear that the nexus between revenue derived from the petrol tax and grants to road funding was at an end. ${ }^{17}$ It is noted that Western Australia (WA) was very much dissatisfied with that decision of the Commonwealth Parliament. ${ }^{18}$ Despite the operations of the Commonwealth funding programme, WA continued to raise an excise on petroleum products consumed in road transport. ${ }^{19}$

For many decades since Federation in 1901, the Australian states have placed excises on alcohol, tobacco and petrol. It is beyond the scope of this paper to consider the validity of State excises and licence fees. It might also be argued that the findings in Matthews $v$ Chicory Marketing Board (Vic) ${ }^{20}$ (Matthews Case) should have put an end to state fuel excises in 1938. However, the 1960 decision in Dennis Hotels Pty Ltd $v$ Victoria ${ }^{21}$ left some room for the states to levy licence fees, with the fees being structured on a volumetric basis. In 1979, the State of Western Australia introduced a licence fee on the sale of petroleum products at the rate of 0.9 cents per litre of motor spirit sold by wholesalers. ${ }^{22}$ Finally, in 1996, the High Court decision

11 Commonwealth Aid Roads Act 1954 (Cth) s 7.

12 Commonwealth Aid Roads Act 1954 (Cth) s 9 (2)(a).

13 Commonwealth of Australia Constitution Act 1900 (Imp) 63 \& 64 Vict, c 12, s 96.

14 Commonwealth Aid Roads Act 1959 (Cth) s 4.

15 Commonwealth of Australia, Parliamentary Debates, Senate, 7 May 1959 (Agnes Robertson, Senator for Western Australia).

16 Commonwealth of Australia, Parliamentary Debates, House of Representatives, 29 April 1959 (Joseph Clark, Member for Darling)

17 The states responded with their own state Road Maintenance (Contribution) Acts. The acts established a motor vehicle licence fee based on the tare weight and carrying capacity of that vehicle - the heavier the vehicle, the greater the fee or contribution to road maintenance.

18 Commonwealth, above $\mathrm{n} 15$.

19 Acts Amendment and Repeal (Road Maintenance) 1979 (WA) s 47N.

20 (1938) 60 CLR 263.

$21 \quad(1959-1960) 104$ CLR 529.

22 Acts Amendment and Repeal (Road Maintenance) 1979 (WA) s 47N. 
in the Ngo Ngo Ha \& Ano v New South Wales (1996) ('Ngo Ngo Ha Case') 23 brought about the end of the state powers to tax alcohol, tobacco and petrol, and excises levied on those products are now the exclusive realm of the Commonwealth of Australia. ${ }^{24}$

Although a detailed examination of that case is also beyond the scope of this paper, it is important to recognise that as a consequence of the $\mathrm{Ngo} \mathrm{Ngo} \mathrm{HaCase} \mathrm{in} \mathrm{1997,} \mathrm{it} \mathrm{was} \mathrm{agreed}$ by the state governments of Australia that the Commonwealth would place levies on alcohol, tobacco and petrol for and on behalf of the states. ${ }^{25}$ The concept of state fuel levies hypothecated for the construction and maintenance of the roadways was at an end. The clarification of the Australian Parliament's budgetary position in 2000 makes it clear that there is no nexus between fuel excise and roadway construction and maintenance expenditure. Therefore, regardless of the impact of changing technology on 'road tax revenue', it is unrelated to road construction and maintenance expenditures. Further, on 1 July 2000, the 1997 tax-sharing arrangements with the Commonwealth ceased with the introduction of Australia's goods and services tax (GST). ${ }^{26}$ It was agreed by the states and the Commonwealth that the Commonwealth would 'legislate to provide all of the revenue from the GST to the States and Territories.' $^{27}$ The states were then, at more than any other point since the Federation, financially dependent on the Commonwealth Government.

Although the hypothecation of road tax revenue exclusively allocated to the construction and maintenance of roadways was terminated in 1959, in 2014, the federal treasurer declared a nexus between road tax revenue and 'new road infrastructure projects' ${ }^{28}$ That statement may have consolidated the general belief that road tax revenue is once more hypothecated to the construction and maintenance of roadways, albeit unofficially. In order to provide the background and context, as well as define the scope of research supporting this paper, the following section examines the previously published research findings on the impact of the introduction of electric vehicles to the transport sector.

\section{REVIEW OF THE PUBLISHED LITERATURE}

23 Ngo Ngo Ha and Anor v New South Wales [1996] HCA 17; handed down 1997.

24 A more complete background on the impact of the Ngo Ngo Ha case on Australian fuel excises can be found in Alexander Robert Fullarton, 'The Apparition of Tax Reform: A Paper That Examines the Issue of Taxation Reform in Australia' (November 14, 2003) Social Science Research Network (SSRN) $<$ https://ssrn.com/abstract=3002871> at 20 July 2017.

25 Council of Australian Governments, Intergovernmental Agreement on the Reform of Commonwealth-State Financial Relations - 25 July 1999, (1999)

<https://www.coag.gov.au/sites/default/files/agreements/reform_of_commstate_financial_relations_PDF.pdf> at 18 February 2018.

26 Ibid.

27 Ibid.

28 Senate Standing Committee on Economics, Parliament of Australia, Fuel Indexation (Road Funding) Bill 2014 and 3 Related Bills (2014) [2.16]

<https://www.aph.gov.au/Parliamentary_Business/Committees/Senate/Economics/Fuel_Indexation_2014/ Report/c02> at 1 March 2018. 
Mortimore has considered encouraging the introduction of electric vehicles as a method of reducing the greenhouse gas emissions produced by the transport sector. In 2014, Mortimore stated that

[t]he transport sector is arguably the most difficult and expensive sector in which to reduce greenhouse gas emissions (GHG), with carbon dioxide (CO2) generated by transport in Australia increasing by 50.7 percent (93.5 Mt CO2-e) in 2012-2013 from 1990 levels (62.0 Mt CO2-e). Unless the government reverses this trend, $\mathrm{CO} 2$ emissions will continue to rise and offset the gains made in reducing carbon emissions in other energy sectors. The largest contributor to transport GHG emissions is road transport. ${ }^{29}$

Mortimore suggested using a taxation system to drive the transition towards adopting electric vehicles. She stated 'that vehicle taxes [could be] reformed into an environmental tax.' She stated that a tax based on vehicle greenhouse gas emissions "is a "powerful instrument" that can "drive consumer demand towards fuel efficient cars" and foster a more sustainable car market. ${ }^{30}$ Everett and Boyle considered alternative fuels to petrol and diesel, which are currently chiefly used as transport fuels. They focussed on the use of hydrogen as an alternative fuel and found that 'a hydrogen alternative could be sold at a similar price [to petrol and diesel] and still have room for taxation. ${ }^{31}$

Twidell and Weir also considered alternative fuel sources. They looked at the concept of introducing bio-fuels as a substitute, or supplement, to the use of fossil fuels in transport. In pointing to the cost of bio-fuels in relation to the petroleum industry, they noted that

the great majority of governments tax automotive petroleum fuels, e.g. the UK with $\sim 400 \%$ total taxation. Such taxation both raises revenue and discourages unnecessary driving to reduce pollution, road congestion and, usually, imports costing foreign exchange. ${ }^{32}$

Their findings suggest that the use of alternative fuels would not affect tax revenue, as the fuel tax is simply varied to accommodate the changing fuel source. However, significant reductions in the consumption of oil-based energy sources could be achieved if electric vehicles were powered from renewable energy sources. Fullarton observed that 'while electric cars are a step forward in reducing greenhouse gas emissions created by motor vehicles, the electricity to refuel these electric cars is derived from fossil fuel generators.' ${ }^{33}$

29 Anna Mortimore, 'Reforming Vehicle Taxes on New Car Purchases Can Reduce Road Transport Emissions_- Ex Post Evidence’ (2014) 29 Australian Tax Forum 177, 179.

30 Ibid 216.

31 Robert Everett and Godfrey Boyle, 'Integration' in Godfrey Boyle (ed), Renewable Energy: Power for a Sustainable Future (Oxford University Press, 2nd ed, 2004) 383, 410.

32 John W Twidell and Anthony D Weir, Renewable Energy Resources (Taylor and Francis, 2nd ed, 2006) 392-3.

33 Alexander Robert Fullarton, Watts in the Desert: Pioneering Solar Farming in Australia's Outback (Ibidem Verlag, 2016) 186. 
Casals et $\mathrm{al}^{34}$ and Lombardi et $\mathrm{al}^{35}$ also point to the need to align renewable, non-polluting electricity sources with the operations of electric vehicles. Otherwise, the gains in reduced fossil fuel consumption and greenhouse gas emissions of the vehicle will be offset by increased fuel consumption and emissions at the power source of the electricity grid.

Further, while some vehicles purport to be 'electric', they continue to consume petrol or diesel, albeit in reduced volumes. Many electric vehicles are really 'hybrids' that rely on 'on board' fossil-fuelled generators to increase the useable range of the vehicle. Therefore, the move from fossil-fuelled internal combustion engine-powered road vehicles to electric vehicles may have little impact on the overall consumption of fossil-fuels and their accompanying greenhouse gas emissions.

However, the introduction of electric vehicles might also provide access to an alternative, untaxable fuel source - self-generated renewable energy. Therefore, the introduction of electric vehicles could significantly displace fossil-fuel energy sources with renewable energy and cause road tax revenues levied on fossil-fuels to decrease significantly. Passey, Watt and Macgill consider the financial impact of self-generated electricity sourced from solar photovoltaic (pv) systems to fuel electric vehicles. ${ }^{36}$ Although they do not specifically examine the impact of self-generated renewable energy for use in electric vehicles on tax revenue, they found that diverting solar pv energy to plug-in electric hybrids (PHEVs) caused

other customers' bills [to be] slightly higher than would be expected. This is because the greater on-site use of PV electricity by the 'Responsible customer' [solar pv and PHEV owner] decreases revenue for Transmission Network Service Providers and Distribution Network Service Providers, and so under the revenue cap scenario they increase their tariffs to compensate. ${ }^{37}$

While Passey, Watt and Macgill do not directly address the concept of tax revenue from road users, they suggest that if electricity vendors are to experience a decrease in revenue from the use of self-generated renewable energy to 'fuel' electric vehicles, then road tax revenue will decrease accordingly. Tax revenue generated from road users is an important source of government revenue. Therefore, despite the cessation of the hypothecation of road tax revenue for the construction and maintenance of roadways by the Commonwealth government in 1959, it is acknowledged that government revenues have often been directed at constructing and maintaining roadways. Nonetheless, despite the threat to road tax revenue from taxes on fossil fuels, governments are being forced to address the issue of atmospheric pollution. In 1997, Briggs et al stated that

[d]espite the major improvements in air quality seen in many European cities over the last 30 40 years, the problem of urban air pollution remains. Levels of traditional pollutants, such as

34 Lluc Canals Casals et al, 'Sustainability Analysis of the Electric Vehicle Use in Europe for CO2 Emissions Reduction' (2016) 127 Journal of Cleaner Production 425

<https://www.sciencedirect.com/journal/journal-of-cleaner-production/vol/127> at 18 February 2018.

35 Lidia Lombardi et al, 'Comparative Environmental Assessment of Conventional, Electric, Hybrid, and Fuel Cell Powertrains Based on LCA'(2017) The International Journal of Life Cycle Assessment <https://link.springer.com/article/10.1007/s11367-017-1294-y> at 7 November 2017.

36 Robert J Passey, Muriel Emmeline Watt and Iain Macgill, 'The Financial Impacts of PV Systems and Plug-in Hybrid Electric Vehicles on Customers Who Do Not Have Them' (Paper presented at the 2014 Asia-Pacific Solar Research Conference, University of New South Wales, 8 December 2014).

$37 \quad$ Ibid 9. 
smoke and sulphur dioxide (SO2) have declined, as a result of industrial restructuring, technological changes and pollution control, but the rapid growth in road traffic has given rise to new pollutants and new concerns. ${ }^{38}$

Yet it was to be 20 years before world governments began to take positive action to reduce greenhouse gas emissions from the transport sector. In 2017, Ali et al note that world governments are taking action to severely curtail greenhouse gas emissions from all sectors of the transport sector, including those from passenger cars.

They state:

Currently, air pollution is a serious issue, especially in heavily populated cities, such as London, Paris, Beijing, and Tokyo. Approximately 25\% of global CO2 emissions are due to passenger road and air travel, and the transport of goods. In addition to CO2, Sox [sulphur dioxide] and Nox [nitrogen dioxide] are also generated. ${ }^{39}$

Falcão, Teixeira and Sodré conclude that while electric vehicles emit lower amounts of greenhouse gases, 'the total cost of ownership is 2.5 times higher than the conventional vehicle. ${ }^{40}$ They also point to the use of renewable energy sources to drive down $\mathrm{CO}_{2}$ emissions. ${ }^{41}$ The use of renewable energy sources is relevant to the case study used in the research supporting this paper. However, this paper disputes the comparative costs of electric vehicles to conventional vehicles assumed by Falcão, Teixeira and Sodré. The PHEV used in this research has comparable capital costs and on-road licensing fees equal to the same model of the petrol-fuelled version of the Mitsubishi Outlander.

Desbarats considers the concept of trading 'carbon credits' from the savings of reduced carbon emissions. While she focuses on reducing carbon emissions generally, she notes that 'emissions trading may simply result in the purchase of offsets depending on the price of carbon. ${ }^{42}$ Further, Desbarats notes that

$[u] n l e s s$ vehicle owners are able to purchase carbon credits to offset deductions from their carbon accounts, their only alternative to minimising their own vehicle use is to either drive less or to

38 David John Briggs et al, 'Mapping Urban Air Pollution Using GIS: A Regression-Based Approach' (1997) 11(7) International Journal of Geographical Information Science 699, 699 <http://www.tandfonline.com/doi/abs/10.1080/136588197242158> at 18 February 2018.

39 Syed Abid Ali Shah Bukhari et al, 'Future of Microgrids with Distributed Generation and Electric Vehicles' in Wen-Ping Cao and Jin Yang (eds) Development and Integration of Microgrids (Intech, 2017) $55<$ https://www.intechopen.com/books/howtoreference/development-and-integration-ofmicrogrids/future-of-microgrids-with-distributed-generation-and-electric-vehicles> at 18 February 2018.

40 Eduardo Aparecido Moreira Falcão, Ana Carolina Rodrigues Teixeira and José Ricardo Sodré, 'Analysis of CO2 Emissions and Techno-economic Feasibility of an Electric Commercial Vehicle' (2017) 193 Applied Energy $297<$ https://www.sciencedirect.com/science/article/pii/S0306261917301794> at 18 February 2018..

41 Ibid 305.

42 Jane Desbarats, An Analysis of the Obstacles to Inclusion of Road Transport Emissions in the European Union's Emissions Trading Scheme (Institute for European Environmental Policy, 2009) $<$ https://ieep.eu/publications/an-analysis-of-the-obstacles-to-inclusion-of-road-transport-emissions-in-theeuropean-union-s> at 29 October 2017. 
purchase low emission vehicles. This would help drive purchases of electric vehicles and could help incentivise the purchase of low carbon fuels. ${ }^{43}$

Her findings are important to the case study in this research, as the PHEV used is charged from a renewable energy resource which has been registered to create renewable energy credits. Therefore, the carbon credits created from 'fuelling' the vehicle further offset the operating cost of the vehicle and are included in this analysis. Of significance to this research is the ultimate impact of the uptake of electric vehicles by mainstream consumers. The outcomes discussed above rely entirely on the volume and rate of uptake of electric vehicles by road users. The transition to electric vehicles will be influenced by a range of social and economic factors, as well as government environmental policies and fiscal incentives.

The Australian Commonwealth Scientific and Industrial Research Organisation (CSIRO) has released a number of reports on studies of the introduction of electric vehicles and projections of future road transport revenues since $2000 .{ }^{44}$ The reports are generally mathematical projections and forecasts of estimations based on a given series of variable factors. However, they are not intended to be relied on as scientific data, but rather to serve as a guide to what may or may not happen given certain assumptions of generally economic factors.

It is also noted that the reports carry a disclaimer:

CSIRO advises that the information contained in this publication comprises general statements based on scientific research. The reader is advised and needs to be aware that such information may be incomplete or unable to be used in any specific situation. No reliance or actions must therefore be made on that information without seeking prior expert professional, scientific and technical advice. ${ }^{45}$

The reports examined attempt to quantify various economic impacts to revenue caused by the introduction of electric vehicles. ${ }^{46}$ Generally, they find that there will be little overall fiscal impact to households until 2050. They suggest overall energy costs to households to power motor vehicles may simply move from purchases of fossil fuel to purchases of electricity. According to the Australian Government Department of Industry and Science, 27.3 per cent of Australia's energy production for the 2013-14 fiscal year was consumed by the transport industry. ${ }^{47}$ Road transport, which is the sector that is the focus of this paper, amounted to just short of three quarters $(72.8 \text { per cent })^{48}$ of the total energy consumption of the transport

43 Ibid 16.

44 Tom Campey et al, Low Emissions Technology Roadmap (Commonwealth Scientific and Industrial Research Organisation, 2017); Paul W Graham and Luke J Reedman, Projecting Future Road Transport Revenues 2015-2050 (CSIRO Research Publication Repository, 2015) <https://publications.csiro.au/rpr/home>; Paul W Graham and Alan Smart, Possible Futures: Scenario Modelling of Australian Alternative Transport Fuels to 2050 (Commonwealth Scientific and Industrial Research Organisation, 2011) <https://publications.csiro.au/rpr/home> at 1 November 2017.

45 Graham and Reedman, above n 44.

46 Commonwealth Scientific and Industrial Research Organisation publications, above n 44.

47 Australian Government, Department of Industry and Science, Australian Energy Update (Office of the Chief Economist, 2015) <https://industry.gov.au/Office-of-the-Chief-

Economist/Publications/Documents/aes/2015-australian-energy-statistics.pdf> at 1 November 2017.

Ibid 14. 
industry. An almost equal amount of energy was consumed in the production of electricity, ${ }^{49}$ and combined with the energy consumed by the manufacturing sector, the three sectors made up nearly three quarters of Australia's energy consumption in 2013-14.

Currently, as coal and natural gas are not used as energy sources for road transport, the 38.4 per cent contribution to Australia's energy sourced from oil ${ }^{50}$ is considered to be primarily consumed by road transport. The introduction of the electric vehicle will not change this, as such vehicles are likely to be charged from fossil-fuelled electricity distribution networks.

It is also acknowledged that a considerable volume of diesel fuel is consumed in electricity generation, particularly in smaller generation systems such as power stations with a generational capacity of less than 15 megawatts. Further, a diesel fuel rebate scheme is provided by the Australian Government to return most of the fuel excise paid by the operators of stationary engines. Therefore, diesel fuel consumed by power stations is outside the scope of this paper. In addition, certain heavy transport vehicles receive a diesel fuel rebate in compensation for part of the fuel excise. Almost from the outset of the rise of the motor car in the early $20^{\text {th }}$ century, governments have raised revenue for roadways primarily from taxes levied on fuel, as well as licensing and registration fees.

In Australia, it may be considered that the major revenue source for the maintenance of the road transport infrastructure, and the construction and maintenance of roadways, is the excise raised from the sale of petroleum products to fuel motor vehicles. The introduction of electric vehicles will greatly reduce motor vehicle petroleum fuel consumption. Therefore, that revenue source for road maintenance expenditure may be in jeopardy.

In particular, that concern was expressed in a 2016 CSIRO report, which states:

EVs will impact government road revenue, particularly fuel excise and government may eventually move to find another way to recover costs which could moderate uptake (e.g. a reduction in fuel excise in favour of a kilometres travelled based mechanism would improve the relative competitiveness of internal combustion vehicles). ${ }^{51}$

According to the report, it is estimated that hybrid and electric vehicles will comprise up to 20 per cent of light duty road vehicles by $2035 .{ }^{52}$ Schott, Püttner and Müller also point to a considerable rise in the electric vehicle market. They state that '[i]n 2011, about 45,000 EVs were sold worldwide, but in the following year, sales soared up to 113,000 , which implies a

49 Ibid. It is noted that the Dept of Industry and Science does not consider electricity to be an energy source. It is considered only as a means of conversion and transportation of energy, rather than as an input to energy production. This is important to this paper, as the focus of the paper is the shift in energy source from fossil fuels to renewable energy for road transport. Excluding electricity as an energy source eliminates possible errors due to the duplication of data.

50 Ibid 11.

51 Paul W Graham and Thomas S Brinsmead, Efficient Capacity Utilisation: Transport and Building Services Electrification (Commonwealth Scientific and Industrial Research Organisation, 2016) <https://publications.csiro.au/rpr/home> at 1 November 2017.

52 Ibid 1. 
market growth of $150 \% .{ }^{53}$ The ABS statistics examined in this paper reveal significant growth rates in the uptake of electric vehicles by Australian motorists in the period 2011-16.

However, the projections of the market penetration of electric vehicles may be somewhat enthusiastic. Schott, Püttner and Müller point to the very small numbers of electric vehicles existing on worldwide roadways. Despite the impressive growth rate in market share, they caution:

Nevertheless this market growth has to be kept in perspective. The global EV stock amounts to as few as 180,000 cars and represents therefore only $0.02 \%$ of the total stock of cars in the world. Related to the worldwide car sales, EV sales have a share of $0.14 \%$ [in 2013]. ${ }^{54}$

As shown in table 1 below, the volume of electric vehicles on Australian roadways was just 0.02 per cent in 2013. That ratio of electric vehicles to all vehicles on Australian roadways is comparable to the global statistics quoted by Schott, Püttner and Müller. Despite the desire by governments and societies to move away from internal combustion engine-powered vehicles for environmental reasons, ${ }^{55}$ Schott, Püttner and Müller point to a raft of barriers to the transition to electric vehicles. ${ }^{56}$ Even though current empirical sales evidence points to an extremely restricted transition to electric vehicles, they state:

the influence of electric vehicles on the global automotive market continues to be very small. Currently they represent only $0.14 \%$ of total passenger car sales. But according to political aims and various scenarios [discussed by them], a dynamic market growth of electric vehicles may be expected in the next years. If this development is borne out, the automotive market will undergo substantial changes. ${ }^{57}$

Despite current market penetration statistics indicating that high volumes of electric vehicles are unlikely to be on Australian or global roadways for decades, there are a range of factors which could result in a sudden and sharp uptake of electric vehicles within the next 10 years. Jochem et al state that 'a successful market penetration of (partially) electrified vehicles seems highly probable.'58 They examine a very broad range of forecasting methods from a wide variety of sources, though predominantly from the United States and Europe, to establish a spectrum of factors which will influence decision makers to transition to electric vehicles in one form or another. They state:

[A]ll decision-makers consider (at least implicitly) the following decision factors:

53 Benjamin Schott, Andreas Püttner and Martin Müller, 'The Market for Battery Electric Vehicles' in Bruno Scrosati, Jürgen Garche and Werner Tillmetz (eds) Advances in Battery Technologies for Electric Vehicles (Woodhead Publishing, 2015) 35, 37.

54 Ibid.

55 Ibid 40-2.

56 Ibid 42-5.

57 Ibid 47.

58 Patrick Jochem et al, 'Methods for Forecasting the Market Penetration of Electric Drivetrains in the Passenger Car Market' (2018) 38 Transport Reviews 322, 323

<https://www.tandfonline.com/doi/full/10.1080/01441647.2017.1326538> at 5 March 2018. 
- Personal beliefs and attitudes (micro-level), such as innovativeness, environmental attitudes, preferences for different makes and vehicle types, which can be influenced by macro-level factors such as media or politics,

- budget and phase of life (micro level), all decision-makers usually have budget restrictions, and private customers take their current phases of life into consideration (e.g. retirement, etc.),

- mobility patterns (micro level), which refer not only to annual mileage, but also to daily patterns, which might be restricted by the range of some cars,

- external factors (macro level), such as political influences (i.e. incentives), fuel prices and availability of fuelling stations,

- other factors (mainly macro level), which include all other influences. ${ }^{59}$

Despite the lack of statistical support for an expanding market penetration of electric vehicles, a guide that might provide an indicator of the uptake of electric vehicles could be the example of uptake of solar pv installations in Australia.

Fullarton finds that the uptake of solar pv installations in Australia was minimal from 2000-09. It was not until 2010 that Australia experienced a 'surge' in the uptake of consumer-owned solar pv renewable energy generation systems. ${ }^{60}$ At that point in time, a raft of governmentdriven incentives had been introduced to encourage consumer confidence in purchasing small generation-sized solar pv systems for residential properties.

Simpson finds that while there were some environmental considerations expressed by householders who purchased solar pv installations, a significant incentive to install solar pv systems was the economic savings from self-generating one's own electricity and the substantial fiscal government rebates for doing so. ${ }^{61}$ She also points to the influence of government intervention impacting the absorption of 'self-generation electricity systems' by householders. ${ }^{62}$ It is possible that householders who own solar pv systems might view the ownership of an electric vehicle as simply the 'next stage' of transitioning away from fossil fuel dependence. Given that by the end of 2017, over 20 per cent of dwellings in Australia had solar pv systems installed on them, ${ }^{63}$ it is possible that one fifth of Australia's population might consider purchasing an electric vehicle in the future.

Graham-Rowe et al also find that the uptake of electric vehicles depends on a raft of factors other than environmental concerns and capital costs. They consider that

EVs were judged by ICE vehicle standards in relation to cost, performance, convenience, comfort and aesthetics, and intentions to purchase were largely dependent on EVs meeting these standards

59 Ibid 340.

60 Fullarton, above n 33, 24.

61 Genevieve Simpson, 'Network Operators and the Transition to Decentralised Electricity: An Australian Socio-technical Case Study' (2017) 110 Energy Policy 422

<https://www.sciencedirect.com/science/article/pii/S0301421517305463〉 at 18 February 2018.

$62 \operatorname{Ibid} 431$.

63 Data obtained from the Australian PV Institute Internet Website <http://pv-map.apvi.org.au/historical\#4/26.67/134.12> at 5 March 2018 . 
at some future date. Production and marketing of EVs may be more successful if these perceptions, comparisons and concerns are addressed. ${ }^{64}$

Furthermore, they found

... that two PHEV drivers did not plug their vehicle into the electricity supply, instead relying on the ICE and regenerative braking system to charge the vehicle, thereby negating the carbon savings associated with using grid electricity to power their vehicles. ${ }^{65}$

If there was a nexus between fuel tax revenue and roadway construction and maintenance, funding for roads would fall by the same proportion. However, at a federal level, there has not been a direct connection between fuel tax revenue and road expenditures since 1959. Therefore, there should be no impact to road expenditures caused by the transition from internal combustion engines to electric vehicles on Australia's roadways.

Research conducted by Galvin in 2017 is of particular significance to this paper. Galvin's research involves a series of laboratory trials, and the following section looks at those findings to compare them with the findings of the field trials conducted in this research.

\section{GALVIN'S 2017 LABORATORY TEST}

Galvin's 2017 research is based on laboratory condition tests of eight makes and models of electric cars. It is of particular relevance to this research, as the vehicle used in this case study research is one of those used by Galvin, a Mitsubishi Outlander PHEV. The findings from his laboratory trials provide a comparison for the data collated from the field trials of the case study supporting the findings of this paper.

Galvin looks at the fuel consumption rates of a range of similar vehicles to ascertain their contribution to greenhouse gas emissions. He finds that:

Recently a discussion has arisen as to whether e-vehicles do, in fact, reduce overall emissions. For countries generating electricity mostly through fossil fuels, much of the gain at the vehicle itself may be lost at the generating plant. Even for countries which are moving rapidly towards renewable electricity generation, such as Germany, lifecycle analysis shows that emissions and wastes produced in the manufacture of e-vehicles and their batteries can negate most of the gains. ${ }^{66}$

This case study also considers the comparative fuel consumption rates of a Mitsubishi Outlander PHEV. It finds that unless fossil fuel-sourced electricity is displaced by renewable energy, there is no displacement of greenhouse gas emissions as a result of using electric vehicles. Due to losses in the generation and transmission of electricity, the use of electric vehicles may increase the volume of greenhouse gas emissions. Ultimately, the introduction of electric vehicles may have little or no significant impact on Australia's rate of greenhouse gas

64 Ella Graham-Rowe et al, 'Mainstream Consumers Driving Plug-In Battery-Electric and Plug-In Hybrid Electric Cars: A Qualitative Analysis of Responses and Evaluations' (2012) 46 Transportation Research Part A 140, 150 <https://www.sciencedirect.com/science/article/pii/S0965856411001418> at 18 February 2018.

65 Ibid.

66 Ray Galvin, 'Energy Consumption Effects of Speed and Acceleration in Electric Vehicles: Laboratory Case Studies and Implications for Drivers and Policymakers' (2017) 53 Transportation Research Part D 234, $235<$ https://www.sciencedirect.com/science/article/pii/S1361920915301280> at 18 February 2018. 
emissions. Rather, the source of the emissions moves from the exhaust pipes of motor vehicles to the chimney stacks of power stations. However, it finds that the transition from internal combustion engines to electric vehicles may have some impact on road tax revenues from fuel excises. Further, unless consumers can expect economic benefits, the transition to electric vehicles may not be significant in the transport sector. It was found with the rollout of dispersed, embedded solar pv installations that significant government incentives were required. ${ }^{67}$

It remains to be seen if the uptake of electric vehicles will follow the same rate as the uptake of solar pv installations in Australia. However, a discussion on the savings of greenhouse gas emissions, other than the income generated from the creation of renewable energy credits by charging electric cars using renewable energy, is beyond the scope of this paper. This paper explores the possible impact on road tax revenues if the adoption of electric vehicles follows similar adoption rates as those experienced in the uptake of dispersed, embedded solar pv systems by Australian households.

\section{RESEARCH METHOD}

This section considers the research method adopted in this paper to support its conclusions. A mixed research approach has been adopted. That approach uses a quantitative analysis of the published statistics and compares the findings of a case study of the use of a Mitsubishi PHEV in the Northwest of Western Australia.

The research programme is conducted by way of:

- An examination of the Commonwealth Scientific and Industrial Research Organisation (CSIRO) and a statistical analysis of published Australian Bureau of Statistic (ABS) motor vehicle census data and ABS raw data supporting those publications.

An estimate of the growth of substitute renewable energy fuels to power Australia's passenger vehicles is made based on the growth of dispersed embedded solar photovoltaic installations in Australia to indicate a possible impact of the uptake of electric vehicles on tax revenues;

- An examination of Australian Taxation Office (ATO) statistics to establish tax revenue received by the Commonwealth of Australia from the fuel excise tax levied on motorists in Australia. From that revenue, the annual diesel fuel rebate tax expenditure is deducted to establish the net value of the taxation of petroleum products to the Commonwealth Government.

The ABS data are compared to the findings from the examination of the ATO statistics to estimate the contribution of fossil-fuel powered passenger vehicles to the net revenue; and

- Finally, the findings of a case study based on the operation of a Mitsubishi PHEV (Plugin Electric Hybrid Vehicle) Outlander sports utility vehicle (SUV) will be examined to support or refute the statistical analysis. The case study includes an examination of

67 Simpson, above $\mathrm{n} 61$. 
Western Australian Department of Transport registration documents to determine the accuracy of vehicle descriptions - particularly vehicle fuel sources.

Conclusions are made as to the expected impact of fuel excise revenue and to estimate the point at which a significant reduction in revenue might occur as users move away from taxable fossil fuels to untaxable renewable energies. The following section examines reports published by Australian government agencies and published statistics to investigate quantitative support for the assertions that tax revenues raised from road users are declining or are likely to decline in the near future.

\section{GOVERNMENT AGENCY REPORTS}

The paper now considers statistical data provided by the ABS and the ATO to establish the value of fuel excise revenue.

\section{A $\quad$ ABS Statistics}

ABS data shows that the total number of motor vehicles registered in Australia rose 12.33 per cent from 16368383 in 2011 to 18387136 in $2016 .{ }^{68}$ Conversely, by far the greatest numbers of motor vehicles consume liquid fossil fuels, and vehicles powered from 'other sources ${ }^{\prime 69}$ actually declined during that period from 513562 in 2011 to 423635 in 2016. Therefore, in 2016, the proportion of motor vehicles not using petrol or diesel in Australia was only 2.30 per cent. Among passenger vehicles, for the main type of electric vehicle, it was even less, at 2.15 per cent. It is also noted that buses were by far the category of vehicle powered by 'other fuels' at 4.19 per cent in 2016 , down from 4.39 per cent in $2011 .^{70}$

The ABS motor vehicle census of 2016 reveals that of all the vehicles registered in Australia, only 6546 were classified as electric. ${ }^{71}$ That number is extremely modest when compared to the total number of registered vehicles of more than 20 million from 2013 onwards. Overall, passenger vehicles consuming unleaded petrol make up the bulk of Australian road users, with 11801876 of the total of 18387136 motor vehicles registered in 2016, or 64.18 per cent. ${ }^{72}$ It is assumed that the data do not mean that passenger vehicles consume two thirds of motor vehicle fuels, as the 2344653 registered commercial vehicles, trucks and buses consume more than one third of the total fuel consumed due to their higher fuel consumption rates, but nonetheless, passenger vehicles undoubtedly consume the bulk of unleaded petrol and therefore contribute the bulk of fuel tax revenue.

68 Australian Bureau of Statistics, 9309.0 - Motor Vehicle Census, Australia, 31 Jan 2016 (2016) <http://www.abs.gov.au/AUSSTATS/abs@.nsf/DetailsPage/9309.031\%20Jan\%202016?OpenDocument> at 17 February 2017.

69 The ABS data aggregates LPG, dual fuel and electric fuels sources into one category.

70 ABS, above $\mathrm{n} 68$.

71 ABS Motor Vehicle Census 2016 constructed from raw data.

72 ABS, above $\mathrm{n} 68$. 
It is also noted that there may be inaccuracies in the ABS data. Appendix A shows the registration papers for the PHEV used in the case study supporting this research. The 'plug-in hybrid electric vehicle' has been recorded as a petrol-powered vehicle. The error arises from the use of the term 'petrol/hybrid' by the motor vehicle dealer, instead of 'plug-in'. One incorrect registration in 6546 is insignificant, but it does indicate a lack of awareness of the difference between internal combustion engine-powered and electric vehicles, even by motor vehicle distributors. However, as examined later in the case study section of this paper, the clerical misunderstanding of the terminology may not give rise to significant statistical errors at this point in time.

It is likely that passenger vehicles will dominate in the rise of electrically powered vehicles for the foreseeable future, as technology for heavy transport vehicles has not yet been fully developed for the commercial market. Therefore, this paper focuses on passenger vehicles on Australian roads. In order to indicate the impact of the uptake of electric vehicles in Australia, Table 1 shows the growth of licensed electric vehicles on Australian roads for the years 201316.

\begin{tabular}{|c|c|l|l|l|c|}
\hline Year & $\begin{array}{l}\text { Electric } \\
\text { Vehicles }\end{array}$ & $\begin{array}{l}\text { Passenger } \\
\text { Vehicles }\end{array}$ & $\begin{array}{l}\text { Percentage } \\
\text { of EVs }\end{array}$ & $\begin{array}{l}\text { Total } \\
\text { Vehicles }\end{array}$ & $\begin{array}{l}\text { Percentage } \\
\text { of EVs }\end{array}$ \\
\hline 2013 & 4167 & 13000023 & 0.032 & 20757657 & 0.020 \\
\hline 2014 & 4705 & 13297170 & 0.035 & 21313721 & 0.022 \\
\hline 2015 & 5215 & 13549450 & 0.038 & 21785979 & 0.024 \\
\hline 2016 & 6546 & 13815108 & 0.047 & 22249088 & 0.029 \\
\hline
\end{tabular}

Table 1: Growth of electric vehicles in Australia 2013-16. (Source: ABS Motor Vehicle Census data 2013-16) ${ }^{73}$

The actual volume of electric vehicles on Australian roads is trivial, and certainly nowhere near the 20 per cent projected by the $\mathrm{CSIRO}^{74}$ or the 30 per cent according to Crowe's article. ${ }^{75} \mathrm{At}$ a total rate of growth of 57 per cent, or 12 per cent per annum, ${ }^{76}$ the rate of growth is considerable, despite being established from a very low base of just 0.029 per cent of all vehicles. However, according to the ABS data, despite such a considerable growth rate in the

73 This table is compiled from ABS raw data and does not necessarily precisely match published Australian Bureau of Statistics, Catalogue 9309.0 - Motor Vehicle Census, Australia, 31 Jan 2016, which is a count of registered vehicles.

74 Graham and Brinsmead, above n 51, 1.

75 Crowe, above n 6. It is unclear which CSIRO report Crowe is referencing. However, the modelling in the 2016 CSIRO report considers 'a medium projection of 20 percent light duty road electric vehicle adoption by 2035 , consistent with other studies which tend to focus on the next 15-20 years.' Graham and Brinsmead, above $\mathrm{n} 51,1$. It is possible that he used a 'high projection rate for journalistic impact'.

76 Compounded rate to produce an increase of 57 per cent over four years using the factor $f(\mathrm{x})=(1+y) n$. 
number of electric vehicles on Australian roads, by 2035, electric vehicles will only make up less than 1 per cent of all passenger vehicles. ${ }^{77}$

In 2016, the number of electric vehicles was just 6546 vehicles of a total of 13815108 . Given that the annual growth rate of all Australian passenger vehicles is 1.53 per cent, ${ }^{78}$ as revealed in table 1, the total volume of passenger vehicles on Australian roads would be $18435190^{79}$ by 2035 . Table 1 indicates that there has been a compounded growth rate of just 12 per cent over the four years. However, electric vehicles could be registered at increasing exponential rates if the take up was affected by external social and economic influences. While the ABS data shown in table 1 reveals that the market share of electric vehicles on Australian roads in 2016 was less than one half of a per cent $(0.05 \%)$, European and US statistics indicate that electric vehicle sales have increased sharply and exponentially. ${ }^{80}$ Therefore, it is possible that by 2035 , around 20 per cent of passenger vehicles using Australian roads could be powered by electricity.

To achieve a 20 per cent composition of all passenger cars by 2035 , the number of electric vehicles on Australian roads would have to be 3687038 or around 3.7 million. That is considerable growth of around 56225 per cent over the remaining 19 years. To achieve that proportion, the compound rate of annual increase would have to be at the rate of 40 per cent, as shown in figure 1. Figure 1 shows an estimated pattern of the growth rate of electric vehicles given the current statistical data and assumes no other external influence which would cause a shift in demand in the take up of electric vehicles by road users. As indicated by Simpson ${ }^{81}$ and Fullarton, ${ }^{82}$ the transition to electric vehicles could follow the take up rates experienced in the roll out of solar pv systems, which would result in much higher volumes of electric vehicles on Australian roads than those illustrated in figure 1. Commensurately, the increase in electric vehicles would result in considerable decreases in road fuel consumptions and therefore road tax revenue.

77 Calculated at a growth rate of 19 per cent against a growth rate of 6.2 per cent for all passenger vehicles.

78 Compound factor $f(\mathrm{x})=(1+y) n$.

79 From compound interest tables: Number of PVs in $2035=13815108 \times(1.33442244287)=18435190$.

80 Yan Zhou et al, 'Plug-In Electric Vehicle Market Penetration and Incentives: A Global Review' (2015) 20(5) Mitigation and Adaptation Strategies for Global Change 10-1 <https://link-springercom.dbgw.lis.curtin.edu.au/article/10.1007/s11027-014-9611-2> at 5 March 2018.

81 Simpson, above n 61.

82 Fullarton, above n 33 


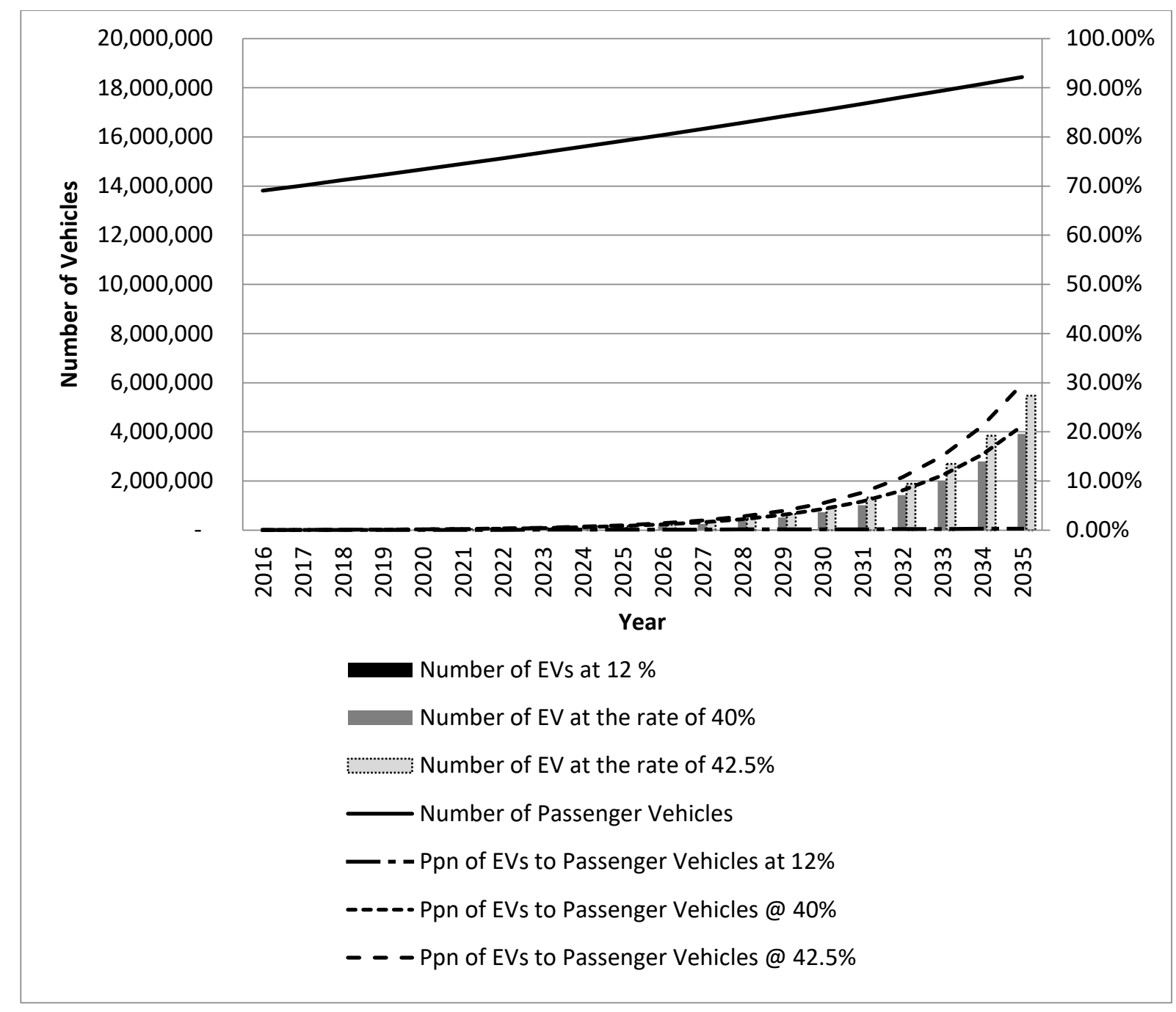

Figure 1: Possible Future Proportions of Electric Vehicles in Australia. (Source: projected from ABS Motor Vehicle Census data 2013-16) ${ }^{83}$

However, figure 1 reveals that the proportions projected by the CSIRO reports (20 per cent) could only be achieved by an annual increase of 40 per cent in the rate of sales of new electric vehicles. It also indicates that with a very slight increase in the take up rate to just 42.5 per cent, the proportion of electric vehicles on Australian roads could be as high as 30 per cent by 2035. However, the current sales trends do not support those estimates. Mitsubishi Australia advises that 'up to the end of CY2016, Mitsubishi had sold 1660 PHEVs in Australia." ${ }^{84}$ That sales data tends to support the ABS statistical data above. Mitsubishi Australia's sales evidence and the ABS statistical data cast significant doubt on an annual increase in electric vehicles to achieve a proportion of 20-30 per cent of Australia's passenger vehicles by 2035. Based on that evidence, it is more likely that electric vehicles will account for less than one half of one per cent of passenger cars within the foreseeable future.

83 This graph is compiled from ABS raw data and does not necessarily precisely match published Australian Bureau of Statistics, Catalogue 9309.0 - Motor Vehicle Census, Australia, 31 Jan 2016, which is a count of registered vehicles.

84 Email from Karl Gehling (Head of Corporate Communications, Mitsubishi Motors Australia Ltd) to Alexander Robert Fullarton, 10 May 2017. 
The rising awareness of environmental influences could also increase the rate at which electric vehicles replace fossil-fuelled passenger vehicles in Australia. There are also environmental benefits in reducing greenhouse gas emissions through the introduction of electric vehicles. Although it is beyond the scope of this paper to investigate the myriad of external influencing factors that could lead to a rapid increase in the rate of uptake of electric vehicles, it is noted that the uptake of roof-mounted solar pv installations in the late 2000s exceeded the expectations of governments and electricity utilities.

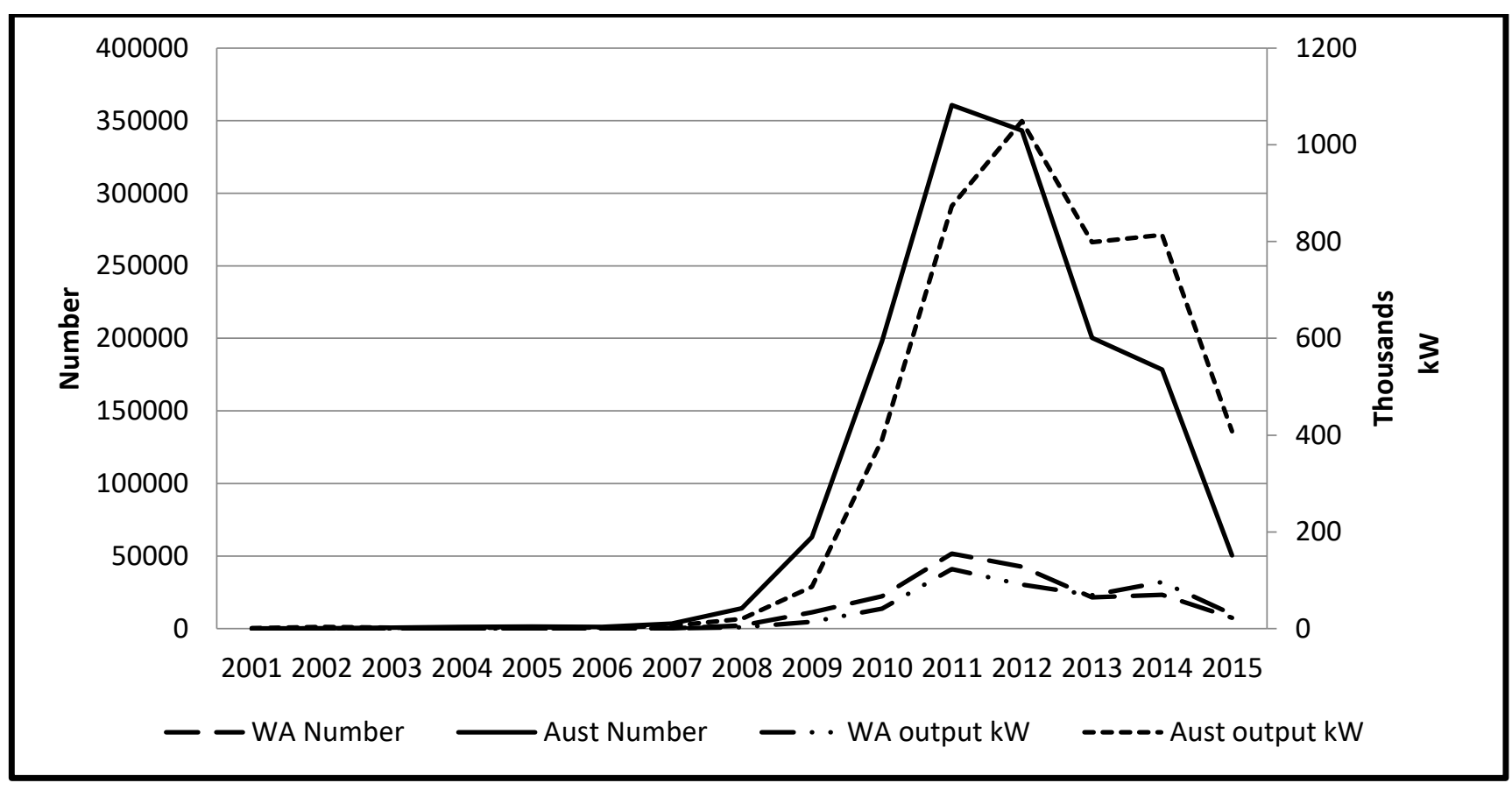

Figure 2: The number of small-scale solar pv installations by year for Western Australia and Australia: 2001-2015.

(Sources: Solex data, Australian Clean Energy Regulator, and Australian PV Institute ${ }^{85}$ )

Figure 2 shows the numbers of small-scale solar pv installations for the years 2001-15. Of significance to this paper is the period 2007-11. Solar pv installations rose from 5689 in 2007 to 360745 by the end of 2011. In just four years, the Australian public had embraced this type of renewable energy by a margin of 6341 per cent. Given similar social and economic influences, the uptake of electric vehicles could replicate the rate of uptake of solar pv installations. Consequently, taxation administrators and policy makers may be well advised to consider the impact of the uptake of electric vehicles sooner rather than later. To determine the likely impact on tax revenue from fuel excises caused by the transition from the internal combustion engine to the electric vehicle, the following section examines published ATO statistics.

\section{B ATO Statistics}

Fuel Excises.

85 Sources: Solex data held by Alexander Fullarton, Australian Clean Energy Regulator, and Australian PV Institute as quoted in Fullarton, above n 33, 4. 
Table 2 shows Australia's fuel excise rates and the total annual fuel excise revenue for the period 2003-04 to 2015-16.

\begin{tabular}{|c|c|c|}
\hline $\begin{array}{c}\text { Year } \\
\text { ended } 30 \text { June }\end{array}$ & $\begin{array}{c}\text { Fuel Excise Rate } \\
\text { Cents/Litre }\end{array}$ & $\begin{array}{c}\text { Excise Revenue } \\
\qquad \$ \mathrm{~m}\end{array}$ \\
\hline 2004 & 38.143 & 13186 \\
\hline 2005 & 38.143 & 13599 \\
\hline 2006 & 38.143 & 13596 \\
\hline 2007 & 38.143 & 14305 \\
\hline 2008 & 38.143 & 14729 \\
\hline 2009 & 38.143 & 14559 \\
\hline 2010 & 38.143 & 14975 \\
\hline 2011 & 38.143 & 15507 \\
\hline 2012 & 38.143 & 16429 \\
\hline 2013 & 38.143 & 16903 \\
\hline 2014 & 38.143 & 17033 \\
\hline 2015 & 38.600 & 17242 \\
\hline 2016 & $39.200-39.500$ & 17468 \\
\hline 2017 & $40.100-40.300$ & tba \\
\hline 2018 & 40.300 & tba \\
\hline
\end{tabular}

Table 2: Australia's Fuel Excise Rates 2004-16.

(Sources: Excise Tariff Amendment (Fuel Indexation) Act 2015 (Cth) ${ }^{86 ;}$ Australian Government data.gov.au ${ }^{87}$ )

The ATO statistics shown in table 2 indicate that in 2003-04, the ATO collected \$13 186 million from road users, and by 2014-15, revenue from the motor vehicle fuel excise had risen to $\$ 17242$ million. ${ }^{88}$ This excise revenue compares to just $\$ 4761$ million being spent by the

86 Excise Tariff Amendment (Fuel Indexation) Act 2015 (No 101) 2015 (Cth).

87 Australian Government, Australian Tax Office Taxation Statistics 2014-15

<http://data.gov.au/dataset/taxation-statistics-2014-15/resource/37b0b252-7c5a-4895-a708db071c54d5fd?inner_span=True > at 25 November 2017.

88 Australian Taxation Office, Organisations/Australian Taxation Office/Taxation Statistics 2014-15/Excise - Table 1 (2017) <http://data.gov.au/dataset/taxation-statistics-2014-15/resource/37b0b252-7c5a-4895a708-db071c54d5fd?inner_span=True> at 12 July 2017. 
Australian government on roadways for the same fiscal year. ${ }^{89}$ However, the Bureau of Infrastructure, Transport, and Regional Economics' (BITRE) statistics reveal that the combined Commonwealth, state and local governments expended \$23 464.8 million on Australian road infrastructures. ${ }^{90}$ However, BITRE also cautions that ' $[\mathrm{t}]$ here may be some double counting of state and local government funding due to lack of data on transfers from state/territory governments to local governments'. ${ }^{91}$

It is noted that the rise of 31 per cent over the 10 year period represents only around 2.47 per cent per annum, ${ }^{92}$ or just below the average Australian rate of inflation in that period. ${ }^{93}$ It is also noted that in 2015, a rise in the excise rate of 1.20 per cent resulted in a rise of 1.23 per cent in excise revenue. However, in 2016, a rise in the excise rate of 2.33 per cent caused the excise revenue to rise by only 1.31 per cent. Two periods are insufficient to indicate a real long-term trend, but the law of diminishing returns may be beginning to apply as consumers seek ways to reduce their fuel consumption. It is also noted that Table 2 shows a fixed excise rate of 38.143 cents per litre for the 11-year period of 2004-14. In fact, the rate had been fixed since 2001, when the Howard Liberal Government ceased the indexation of fuel excise taxes to alleviate the impact of rising petrol prices caused by other economic and political factors. ${ }^{94}$

Biannual indexation of the fuel excise in line with the Australian consumer price index was introduced in 1983 by the Hawke Labour Government to counteract the eroding effects of inflation $^{95}$ on the value of the tax. However, in 2014, the Abbott Liberal Government reintroduced fuel tax indexation, as 'the real value of fuel tax had declined with inflation, 'creating significant difficulties for the government to fund spending commitments, such as new road infrastructure projects'. ${ }^{96}$ It is interesting to note that although formal hypothecation of the fuel excise revenue for the purposes of funding construction and maintenance of roadways ceased in 1959, the Treasurer's speech accompanying the 2014-15 budget appeared to reintroduce the concept.

89 Australian Government, Department of Infrastructure and Regional Development, Bureau of Infrastructure, Transport, and Regional Economics, Key Australian Infrastructure Statistics 20169

<https://bitre.gov.au/publications/2016/files/BITRE_yearbook_2016_pocket_book.pdf> at 13 July 2017.

90 Ibid.

91 Ibid.

92 Average compounded rate of inflation for 12 years.

93 According to ABS data \$17 242 million in 2015 would have been worth \$12 926 in 2004: Australian Bureau of Statistics, Consumer Price Index Inflation Calculator (2017)

<http://www.abs.gov.au/websitedbs/d3310114.nsf/home/Consumer+Price+Index+Inflation+Calculator>at 13 July 2017.

94 Parliament of Australia, Background Papers, Fuel Taxation Inquiry, History of Fuel Taxation in Australia (2001) 2 <http://fueltaxinquiry.treasury.gov.au/content/backgnd/download/002.pdf> at 30 June 2014.

95 Parliament of Australia, Parliamentary Business, Fuel Indexation (Road Funding ) Bill 2014 and Related Bills (2014)

<https://www.aph.gov.au/Parliamentary_Business/Committees/Senate/Economics/Fuel_Indexation_2014/ Report/c02> at 13 March 2018.

Ibid. 
In respect of funding infrastructure, the Regulation impact statement referred to the government's commitment in its 2014-15 Budget to increasing road expenditure. It also drew attention to the connection between the revenue to be raised from the indexation and road infrastructure projects:

An increase in the rate of fuel tax would be used to help these infrastructure projects. This would create a link between users of the road infrastructure and the payers of fuel tax whilst ensuring a predictable and growing source of revenue..$^{97} 98$

In fairness, the statement refers to 'helping' certain 'infrastructure projects' rather than a formal hypothecation of ALL excise revenue to the construction and maintenance of the roadways per se. However, it may explain the belief held by the media and commentators that hypothecation of road revenue to expenditures for road construction and maintenance currently exists in Australia. The following section considers the impact of fuel tax credits refunded or rebated to certain eligible businesses considered to be essential to the Australian economy, such as the heavy transport industry, and off-road users, such as the fishing and agricultural sectors.

Fuel tax credits.

Table 3 shows the impact of fuel tax credits refunded to certain taxpayers in the transport, mining and other industries which are not considered to be road users, such as agriculture, forestry and fishing. Eligible businesses ${ }^{99}$ can claim all or part of their fuel excises as tax rebates.

\begin{tabular}{|c|c|c|c|}
\hline Year & Fuel Excise & $\begin{array}{c}\text { Fuel Tax } \\
\text { Credits } \\
\$ \mathrm{~m}\end{array}$ & $\begin{array}{c}\text { Net } \\
\text { Revenue } \\
\$ \mathrm{~m}\end{array}$ \\
\hline 2005 & 13600 & 3747 & 9853 \\
\hline 2006 & 13593 & 3814 & 9779 \\
\hline 2007 & 14305 & 4309 & 9996 \\
\hline 2008 & 14729 & 4703 & 10026 \\
\hline 2009 & 14559 & 5065 & 9494 \\
\hline 2010 & 14975 & 4994 & 9981 \\
\hline 2011 & 15507 & 5109 & 10398 \\
\hline 2012 & 16429 & 5527 & 10902 \\
\hline
\end{tabular}

97 Regulation impact statement, CPI Indexation of Fuel Excise and Excise-Equivalent Customs Duty [2.6].

98 Parliament of Australia, above n 94.

99 Australian Taxation Office, Fuel Schemes/Eligible Activities (2017)

<https://www.ato.gov.au/business/fuel-schemes/fuel-tax-credits---business/eligibility/eligible-activities/> at 25 November 2017. 


\begin{tabular}{|c|c|c|c|}
\hline 2013 & 16903 & 5408 & 11495 \\
\hline 2014 & 17033 & 5706 & 11327 \\
\hline 2015 & 17242 & 6010 & 11232 \\
\hline 2016 & 17468 & 6082 & 11386 \\
\hline 2017 & tba & tba & tba \\
\hline
\end{tabular}

Table 3: Tax Credits paid to Australian Eligible Off-Road and Heavy Transport Activities. (Sources: 2005-06; ATO Taxation Statistics 2004-05; 2007-16; data.gov.au Taxations Statistics 2014-15/Excise ${ }^{100}$ )

Table 3 indicates that during the period 2005-16, fuel excises rose 28.44 per cent. However, after fuel tax credits had been returned to eligible businesses, the increase in net road revenue from this source only increased by 15.56 per cent overall, or an annual compound interest rate of just 1 per cent. That net increase in revenue closely aligns with the gross revenue analysis shown in Table 2, but at the same time, fuel tax credits to eligible businesses rose by 62.32 per cent or 6 per cent per annum. It is concluded therefore that the bulk of taxed road users are the drivers of passenger vehicles.

Statistical Analysis Conclusion.

The ATO data indicates that the burden of fuel excises is borne chiefly by the passenger vehicle sector. Therefore, a change in the proportion of electric vehicles may have a significant impact on net road revenue from that taxation source. However, ABS data indicate that the number of electric vehicles on Australian roads is minimal. Accordingly, even at considerable growth rates in the adoption of electric vehicles, the impact on fuel excise revenue is also negligible. ABS data does not bear out the projections suggested by CSIRO reports and projections. It is possible that external influences could occur that substantially impact the transition to electric vehicles, as experienced with the adoption of dispersed embedded solar pv installations in the late 2000s, but at present, they are little more than speculation.

Sales evidence from one of the major motor vehicle distributors in Australia does not indicate a high take-up of electric vehicles. Rather, sales data from Mitsubishi Motors Australia support the ABS data. The conclusion of the ABS data that the entire number of electric vehicles on Australian roads is less than one half of one per cent is likely to be very accurate. Despite the cessation of the hypothecation of fuel excise revenue to expenditures for roadway construction and maintenance in 1959, making any link between the road revenue source and expenditures on roads non-existent, if fuel excises were to decrease to around one-third of the 2016 levels, they would continue to meet the federal government funding of Australia's roadways.

This examination of statistics concludes that in the unlikely event that electric vehicles were to comprise nearly one-third of vehicles on Australian roads, fuel excises would remain nearly

100 Australian Taxation Office, Research and Statistics; Taxation Statistics (2007) $<$ https://www.ato.gov.au/About-ATO/Research-and-statistics/In-detail/Taxation-statistics/TaxationStatistics-2004-05/?page=41\#Energy_grant_schemes $>$ at 25 November 2017; Australian Taxation Office, above $\mathrm{n} 88$. 
twice the volume of revenue over the current levels of federal expenditures on roadway construction and maintenance.

\section{CASE STUDY}

This section examines a case study of field trials conducted on a Mitsubishi Outlander PHEV. The findings of this case study are compared to Galvin's laboratory trials discussed earlier. The vehicle is owned and operated by the Solex Solar Project in Carnarvon Western Australia. It was used in a rural/urban setting for a period of 17 months from May 2016 to October 2017. It is fuelled from an unleaded petrol engine to power the on-board electricity generation system and an external electricity connection. The power unit for the on-board generation system is a 2L Mitsubishi internal combustion engine.

The engine is a standard power plant used in most Mitsubishis and similar makes and models of sports utility vehicles of comparable size and class. The electricity source is renewable energy-sourced electricity from the Solex solar farm. An electricity meter and a log book are kept to record electrical energy inputs.

It is noted that motor vehicle owners are also levied with a range of other taxes. Table 4 shows a range of taxes applicable to motor vehicles in Australia. It also shows how those taxes might be avoided by the transition from internal combustion engines to electric vehicles.

\begin{tabular}{|l|c|c|c|c|}
\hline \multirow{2}{*}{ Tax } & \multicolumn{4}{|c|}{ Energy Source } \\
\cline { 2 - 5 } & Petrol/diesel & $\begin{array}{c}\text { Mains } \\
\text { Electricity }\end{array}$ & $\begin{array}{c}\text { Self-generated } \\
\text { fossil fuel }\end{array}$ & $\begin{array}{c}\text { Self-generated } \\
\text { renewable } \\
\text { energy }\end{array}$ \\
\hline Fuel Excise & Yes & No & No & No \\
\hline GST & Yes & Yes & Yes ${ }^{101}$ & No \\
\hline Licence/Registration & Yes & Yes & Yes & Yes \\
\hline
\end{tabular}

Table 4: Taxes applicable to alternative motor vehicle fuel sources.

Note that the 2016 Mitsubishi Outlander Plug-In Electric Hybrid vehicle used for this case study is slightly larger and heavier than the 2012 Mitsubishi I MiEV used by Galvin in his laboratory studies. ${ }^{102}$ Detailed specifications of these vehicles are given in this paper, as they can be readily accessed from the manufacturers' websites, although the MiEV is no longer available for sale in Australia. However, to provide reasonable comparisons, the kerb mass and engine power are as follows:

101 The Goods and Services Tax applies to fuel consumed but not to the self-generation of renewable energy.

102 Galvin, above n 66. 
MiEV kerb mass $1305 \mathrm{~kg}$ and engine power of $49 \mathrm{~kW}$; and

Outlander PHEV kerb mass $1810 \mathrm{~kg}$ and $60 \mathrm{~kW}$ combined engine power. ${ }^{103}$

Therefore, it is expected that the heavier mass and power of the Outlander should increase its fuel consumption over that of the MiEV. In addition, the on-road conditions introduce the factor of wind resistance, which is also expected to influence fuel consumption over those data obtained from laboratory condition trials. The Outlander is garaged in Carnarvon Western Australia. It is primarily used for travel within the small town for round trips of less than $20 \mathrm{~km}$. Its fuel source, while in Carnarvon, is exclusively electricity sourced from renewable energy generated by the Solex Solar Farm. It is energised by way of a $15 \mathrm{amp}$ general purpose outlet to a 240 volt AC supply. The vehicle is charged during daylight hours when not in use. The supply is metered, however, no data for the charging times have been kept.

Long range trips of around 1000km were conducted in roughly three-month periods. They are part of normal Solex operations to travel to adjacent towns or to the City of Perth, which is some $900 \mathrm{~km}$ distant from Carnarvon. In that role, the vehicle is no different from the internal combustion engine (ICE) powered vehicles previously used by the owner or the community generally. During the period 30 May 2016 to 1 November 2017, the vehicle travelled $23976 \mathrm{~km}$ (14 899 miles) and consumed 1333.36L (293.29Imp gal) of unleaded petrol in excess of the 90 octane rating. Those data show an average fuel consumption of just $5.56 \mathrm{~L} / 100 \mathrm{~km}(50.81 \mathrm{mpg}$ Imp). In addition, the vehicle also consumed 1423.99kWh of electricity. By applying an estimate of $330 \mathrm{ml}$ of petroleum to produce $1 \mathrm{kWh}$ of dispatchable electricity, ${ }^{104}$ an additional 469.92L (103.37 Imp gal) of unleaded petrol has been displaced.

The total fuel consumption, including the electric charge in equivalent unleaded petrol, is 1803.28L (396.67 Imp gal), which produces an average fuel consumption, including the electric charge, of $7.52 \mathrm{~L} / 100 \mathrm{~km}$ or $37.56 \mathrm{mpg}$ (Imp). A detailed log of trips is shown in Appendix B. Fuel consumption ranges considerably from 1.61L/100km (175.45mpg Imp) for local running in Carnarvon to 7.95L/100km (35.53mpg Imp) for a trip from Perth to Carnarvon against strong to moderate winds in November 2016.

It was noted that wind resistance has considerable influence on the fuel consumption rates of the Mitsubishi Outlander PHEV. When located in Carnarvon, the vehicle is charged regularly with electricity and therefore uses very little unleaded petrol. All of the electricity is sourced from solar pv renewable sources generated from the Solex solar farm. The manufacturer has advertised fuel consumption rates of as low as $1.7 \mathrm{~L} / 100 \mathrm{~km}(166 \mathrm{mpg} \mathrm{Imp}) .{ }^{105}$ An examination of the logbook data, provided in Appendix A, supports that claim - provided the electricity used in charging is not considered in the fuel consumption calculations. Galvin's 2017 laboratory trials of eight electric vehicles focused on energy consumption under acceleration. However, his analysis of four electric vehicles driven under various levels of acceleration for

103 Mitsubishi Motors Owner's Manuals.

104 Santiago Arnalich, Epanet and Development: How to Calculate Water Networks by Computer (Arnalich, Water and Habitat, 2011). Arnalich uses diesel to establish a calculation of $300 \mathrm{ml} / \mathrm{kWh}$. This calculation has been made on the basis that motor petroleum is 88 per cent of the energy contained in diesel. This paper uses the schedule in Part 3 of the National Greenhouse and Energy Reporting (Measurement) Determination 2008 made under subsection 10(3) of the National Greenhouse and Energy Reporting Act 2007 to support the calculation used here.

105 Mitsubishi Motors, Outlander PHEV (2017) <https://www.mitsubishi-motors.com.au/vehicles/outlanderphev> at 5 November 2017. 
a distance of $2.4 \mathrm{~km}$ provides a reasonable comparison with the range of driving conditions of the Outlander PHEV driven in this case study.

Galvin's data reveal an average energy consumption of $1956621 \mathrm{~W} / \mathrm{s}$ over $2400 \mathrm{~m}^{106}$ or $22.65 \mathrm{kWh} / 100 \mathrm{~km} .{ }^{107}$ By applying the energy conversion rate calculated by Arnalich, ${ }^{108}$ an equivalent fuel consumption rate of $7.47 \mathrm{~L} / 100$ is established. ${ }^{109}$ That is very close to the fuel consumption rate established in this case study. The published anticipated fuel consumption rates of vehicles similar to the Outlander PHEV are contained in table 5 to provide a comparison between the established PHEV fuel consumption and that of its petrol-fuelled competitors. This discussion on the comparative fuel consumptions of a range of similar vehicles is to estimate how much fossil fuel will be avoided, and hence, the reduction in fuel tax revenue, caused by the transition to electric vehicles.

\footnotetext{
106 Galvin, above n 66, 243.

$1071 \mathrm{kWh}=3600000 \mathrm{~W} / \mathrm{s}(1 \times 60 \times 60 / 1000)$.

108 Arnalich, above n 104.

$10922.65 / 0.33=7.4745$.
} 
2018 Journal of Australian Taxation - Volume 20 - Art 2 Fullarton

\begin{tabular}{|l|c|}
\hline \multicolumn{1}{|c|}{ Make and Model } & Published fuel consumption \\
\hline Mitsubishi Outlander PHEV 1GAV414 & $\begin{array}{c}\text { Established } \\
7.52 \mathrm{~L} / 100 \mathrm{~km}^{110}\end{array}$ \\
\hline Mitsubishi Outlander PHEV & $1.7 \mathrm{~L} / 100 \mathrm{~km}^{111}$ \\
\hline Ford Escape 1.5L & $7.5 \mathrm{~L} / 100 \mathrm{~km}^{112}$ \\
\hline Kia Sportage Si 2.0L & $7.9 \mathrm{~L} / 100 \mathrm{~km}^{113}$ \\
\hline Mitsubishi Outlander - AWD petrol 2.4L & $7.2 \mathrm{~L} / 100 \mathrm{~km}^{114}$ \\
\hline Nissan Qashqai ST 2.0L & $7.7 \mathrm{~L} / 100 \mathrm{~km}^{115}$ \\
\hline Subaru Forester 2.0L & $7.2 \mathrm{~L} / 100 \mathrm{~km}^{116}$ \\
\hline Toyota RAV 4 2.0L & $7.7 \mathrm{~L} / 100 \mathrm{~km}^{117}$ \\
\hline
\end{tabular}

Table 5: Comparative Published Fuel Consumption for a Range of Vehicles similar to the Outlander PHEV.

(Sources: Motor Vehicle Manufacturers' Internet Websites as referenced)

The published fuel consumption of the petrol-fuelled internal combustion engines of the comparable makes and models reveals that around $7.5 \pm 0.3$ litres of unleaded petrol are required to move a sports utility vehicle of around $2000 \mathrm{~kg}$ for a distance of $100 \mathrm{~km}$ at moderate driving speeds. Those data closely correlate with the findings of this case study and Galvin's 2017 laboratory trials of similar vehicles. The manufacturers' publications, which disclose a

110 Case Study Log Book recordings.

111 Mitsubishi Motors, Outlander PHEV (2017) <https://www.mitsubishi-motors.com.au/vehicles/outlanderphev> 5 November 2017.

112 Ford Motor Company of Australia Limited 'Explore ESCAPE Escape Ambiente 1.5L EcoBoost Petrol AWD’<https://www.ford.com.au/suv/escape/models/ambiente-awd/?intcmp=vhp-return-model $>$ at 6 November 2017.

113 Kia Motors Corporation, Sportage (2017) <http://www.kia.com/au/cars/sportage/specification.html> 6 November 2017.

114 Mitsubishi Motors, Outlander AWD Petrol (2017) <https://www.mitsubishimotors.com.au/vehicles/outlander/specifications/outlander-awd-petrol> at 6 November 2017.

115 Nissan Motor Co (Australia) Pty Ltd, Nissan Qashqai (2017) <http://www.nissan.com.au/ /media/Files/Brochures/Specifications/QASHQAI/QASHQAI\%20Spec\%20J ul\%202015.ashx> at 6 November 2017.

116 Subaru (Australia) Pty Ltd, Subaru Forester (2017) <https://www.subaru.com.au/forester/performance> at 6 November 2017.

117 Toyota Motor Corporation Australia Limited, RAV 4, GX 2.0L petrol 5D Wagon (2017) $<$ http://www.toyota.com.au/rav4/specifications/gx-2-01-petrol-5d-wagon-6-manual-2wd> at 6 November 2017. 
fossil fuel consumption rate of around $2 \mathrm{~L} / 100 \mathrm{~km}$, do not appear to take the fossil fuel equivalent for the generation of the electrical charge of around $24 \mathrm{kWh} / 100 \mathrm{~km}$ into consideration.

In conclusion, those findings are consistent with the principles of physics of work, power and energy. ${ }^{118}$ It is simple physics that the energy required to carry out the movement of a certain mass, over a certain distance, within a certain time, will always be the same, no matter what the energy source is. The relevance to this paper is that if vehicles were powered entirely from self-generated renewable electricity, for example, domestic solar pv systems, then the only road tax revenue levied is that from the registration of the vehicle, as illustrated in table 4.

The case study found that unless electricity is provided from renewable energy sources, there is no impact on fuel consumption rates between the PHEV used in this case study and similar makes and models of internal combustion engine driven passenger vehicles. If the PHEV is fuelled entirely from its on-board petrol-driven generation system, then there is no impact on fossil fuel consumptions. If the PHEV is fuelled entirely from the main electricity sources, and in particular, fossil fuel-based power stations, there will be no impact on greenhouse gas emissions, other than to emit them from the power station rather than the vehicle itself. Likewise, fuel consumption rates remain the same as for fossil-fuelled vehicles.

Given that fossil fuel for power stations is not levied by way of the fuel tax credit system, if all electricity is sourced from the main supplies, the fuel excise is avoided. At the rate of $4 \mathrm{~km} / \mathrm{kWh}$ or $12 \mathrm{~km} / \mathrm{L}$, a distance of $24000 \mathrm{~km}$ travelled amounts to $2000 \mathrm{~L}$ or a fuel excise impost of $\$ 800$ is avoided. ${ }^{119}$ In this case, some $6700 \mathrm{kWh}$ would have been consumed and would have cost $\$ 2000$ at 2017 ruling rates for electricity in Western Australia. That would have provided around $\$ 180$ in GST. The cost of avoided tax to the federal government is reduced to just over $\$ 600$ per annum or a mere $\$ 11$ per week.

Based on the vehicle use established in this case study, if 5.5 million electric vehicles are to make up the composition of passenger vehicles on Australian roads by 2035, as illustrated in figure 1, then a total fuel excise of $\$ 3300$ million, or 28.98 per cent of the net tax revenue for 2016, would be avoided. ${ }^{120}$ That is almost the proportion of electric vehicles to passenger vehicles in the year 2035 estimated in figure 1. The estimates are co-incidental, as they ignore the growth rates in fuel excise rates. They also assume that electric vehicles are fuelled entirely from off-road fossil fuel energy sources. That is not the case for PHEVs, which have on-board fossil-fuelled electricity generation capacity. Further, there are no concessions for the licensing or other imposts on passenger vehicles afforded to electric cars. Therefore, there is no impact on other road revenues from the passenger vehicle sector of road transport. In addition, other imposts such as the goods and services tax on electricity purchases remain levied on the users of electric vehicles.

\section{CONCLUSION}

118 Stanley Leonard Martin and Andrew Kenneth Connor, Basic Physics 1 (Whitcombe and Tombs Pty Ltd, 1968) 64-76.

119 The distance travelled in this case study at a fuel excise rate of 39.80 cents per litre (The average excise rate for the period under review).

120 Australian Tax Office, above n 99. 
The examination of the data provided by the ABS and ATO did not provide a clear and distinct indication that the proportion of electric vehicles on Australian roadways will escalate to a level that will have a significant impact on fuel excise revenues. ABS data indicated that the proportion of electric vehicles to all passenger vehicles was less than one half of one per cent at the end of the 2016 calendar year. If the current market trend for the take up of electric vehicles continues as illustrated in figure 1, then it will be 16 years before the market penetration reaches a mere 10 per cent of all passenger vehicles on Australian roads. However, given the compounding effect of statistics, it may be possible that electric vehicles will make up nearly one third of all Australian passenger vehicles by slightly later than 2035 .

However, given the PHEV vehicle performance and comparative fuel consumptions as indicated in Galvin's laboratory trials and supported by this case study, the reduction in fossil fuels, and therefore, the impact on greenhouse gas emissions and road tax revenue may be minimal. A commensurate reduction of 30 per cent in fossil fuel consumption, greenhouse gas emissions and road tax revenue will only be possible if all electric vehicles are recharged exclusively by renewable energy-sourced electricity. An anomaly was found in the registration documents of the PHEV used in this case study as shown in Appendix A. It appears that the registration staff have incorrectly registered the 'plug-in electric hybrid' as a petrol-fuelled vehicle, rather than as an electric vehicle. That misclassification might create errors in the accuracy of the ABS data. However, the sales data provided by one of the main motor vehicle manufacturers of electric vehicles supports the ABS data. Therefore, the misclassification may be within tolerable error ranges and of no overall significance.

ATO data reveal that any reductions in fuel excise revenue caused by the transition to electric vehicles are so small as to be irrelevant to national road revenue collections. It also indicates that any reduction in revenue could be readily compensated by equal reductions in fuel tax credits paid to eligible enterprises engaged in heavy road transport or off-road industries. An examination of the legislation supporting fuel excises finds there is no legislative support for the assertion that fuel excises are hypothecated to roadway construction and maintenance in Australia. It was found that until 1997, Western Australia had a fuel levy that may have been intended to contribute to roadway construction and maintenance. That legislation was repealed as a consequence of the findings in the $\mathrm{Ngo} \mathrm{Ngo} \mathrm{HaCase}$ as to the legality of state excises in 1996. The federal government removed hypothecation of fuel excises to roadway construction and maintenance in 1959. Therefore, assertions that the transition to non-petroleum-based passenger vehicles will severely negatively impact expenditures on Australian roads are not supported by this research.

Despite the removal of the hypothecation of funding of roadway construction from fuel excise revenue in 1959, if a connection between road revenue and expenditure is perceived to exist, a relatively simple means of continuing road funding from fuel excises would be to reduce fuel subsidies for fossil fuel purchased by 'eligible enterprises'. In the modern world, where the reduction of greenhouse gas emissions from burning fossil fuel is viewed as a pressing environmental concern, the subsidisation of fossil fuels appears to be incongruous with those social goals. The case study has proven that the 'hybridisation' of coupling an internal combustion engine-powered, on-board generation system with an external electrical charging capability works effectively and efficiently. The vehicle performs a dual role - that of an electric vehicle in an urban setting and an internal combustion engine-powered vehicle for the purposes of long distance travel. 


\section{SUGGESTIONS FOR FURTHER RESEARCH}

This section considers some areas for research beyond the scope of this paper that could be investigated further to develop a broader understanding of the impact of changing technology on the way passenger vehicles are used and powered. First, the impact of electric vehicles on the electricity grid could be researched as the fuel source moves from unleaded petrol provided by existing petrol bowser-type filling stations to standard electrical general-purpose outlets. The introduction of the electric vehicle does not reduce the overall energy demanded by road transport. The energy consumed by road transport will almost certainly remain unchanged, that is, if it does not rise due to population and economic growth. However, the source of energy will change. A looming problem associated with the rise of the electric vehicle is the impact of charging electric vehicles from the existing electrical distribution networks. Du and others have considered the impact of charging electric vehicles from network sources and have suggested a model to optimise charging and discharging electricity to level demand on the power system. They conclude that instead of destabilising the existing electricity networks, electric vehicles

... can be integrated [into the grid and] operated [in a manner] which [is] based on [the] optimization model [presented]. It would have a [beneficial] effect on power system stability. Compare[d] with the only charging methodology, this optimization method is more flexible, stab[le] and efficien[t]. In addition, with the probability of vehicle online respect to [the] power grid, the optimized load profiles would present [a] more practical status. This optimization methodology proposed in [their] paper can be applied in different operational circumstances. For instance, it can be applied in industrial, commercial and residential power demand where detailed information of demand profiles [is] known. ${ }^{121}$

Second, the integration of renewable energy sources in the distribution networks goes some ways towards reducing greenhouse gas emissions and the reliance on fossil fuels. The impact on the rates of greenhouse gas emissions of the introduction of the combination of growing proportions of electric vehicles and the renewable energy electricity sources to power them could be further researched.

Third, the economic impact on households could be researched to quantify the fiscal costs as savings or additional imposts as fuel sources change, in particular, the economic impact on households charging electric vehicles from dispersed, embedded solar pv installations or electricity purchased from the existing fossil fuel-generated utilities. Such an economicallyfocussed study could include the fiscal impact on government revenue and businesses.

Fourth, investigations could be conducted as to the introduction of electric vehicles in the workplace for the purpose of employees commuting from their residences to their places of work. It is suggested that employers could provide electric vehicle charging facilities powered by renewable energy sources. Employers could install roof-mounted solar pv systems and could provide employees with free or heavily subsidised electricity. Employees would benefit from reduced costs of commuting to and from the workplace, and the environment would benefit from reduced greenhouse gas emissions. The economic savings of reduced fuel costs could be shared between the employer and the employees. The introduction of the electric

121 Guanhao Du et al, 'An Optimization Model of EVs Charging and Discharging for Power System Demand Leveling' (Paper presented at the 2016 Institute of Electrical and Electronic Engineers' Power and Energy Society Asia-Pacific Power and Energy Conference, Xi'an, China, 25 October 2016) 841. 
vehicle enables such a transition to renewable energy sources for the road transport sector to develop. It is a transition that is strongly recommended by this paper. 


\section{Appendix A}

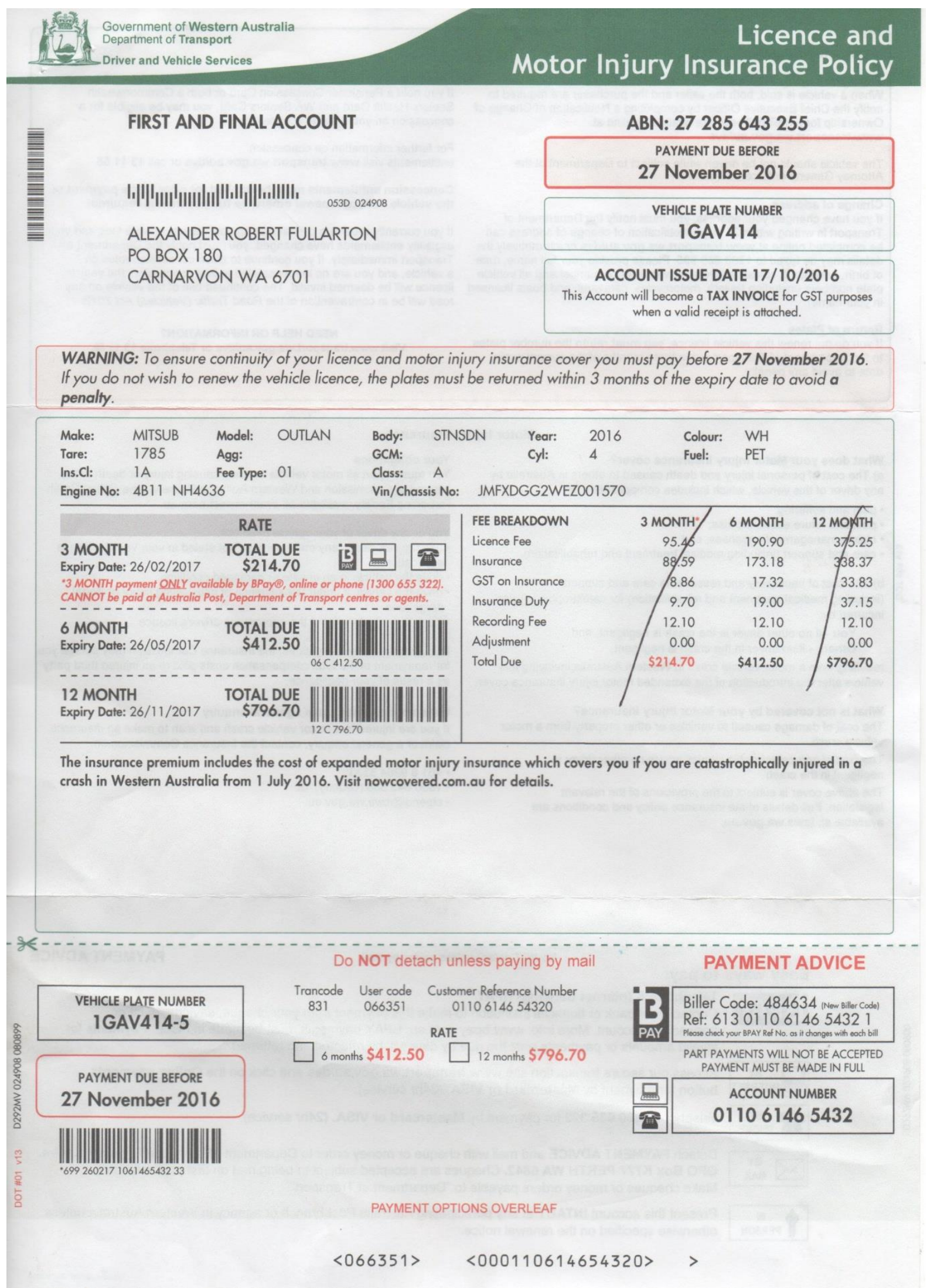

Western Australian Licence Notice for Mitsubishi PHEV Outlander 


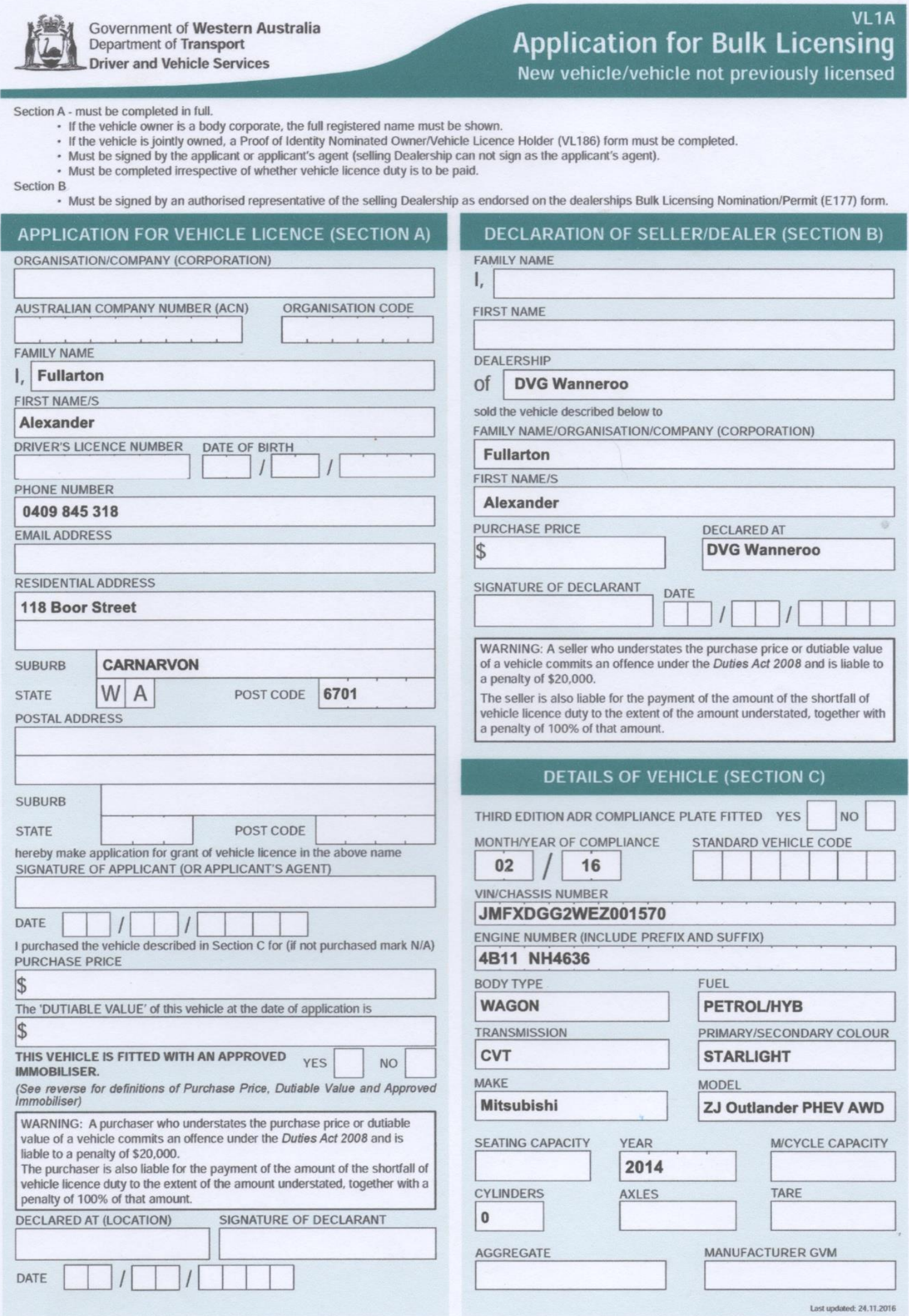




\section{Journal of Australian Taxation - Volume 20 - Art 2 Fullarton}

\section{IMPORTANT INFORMATION}

\section{Section 1 - Scope of Bulk Licensing Scheme}

The Bulk Licensing Scheme permits dealers to certify the accuracy of information submitted and the fitness of motor vehicles or trailers, under the provisions of the Road Traffic (Inspection of Vehicles)Notice 2012, without individual inspection of these vehicles. The Scheme applies to approved dealerships for the licensing of new or not previously licensed vehicles only. relevant to:

- standard vehicles:

standard vehicles with manufacturer's options; and

- vehicles subject to modifications which do not require Chief Executive Officer approval under the Road Traffic (Vehicles) Act 2012 currently in force.

\section{Section 2 - Duties of Authorised Representative}

An authorised representative is required to verify the accuracy of the particulars shown on this form and that:

- the VIN on the VL1A form matches the VIN on the vehicle:

- that the correct number plates have been allocated and will be attached to the vehicle; and

- if the vehicle is a trailer, a VSB1 trailer plate has been affixed by an authorised installer.

PLEASE NOTE: It is an offence under provisions of the Road Traffic (Administration) Act 2008 to wilfully mislead by falsifying and/or incorrectly declaring information on this form.

Section 3 - Definitions

Dutiable value

The term 'dutiable value' is defined by Division 5 of the Duties Act 2008 .

The following interpretation is provided as a guide only.

'Purchase Price', in respect of a vehicle, includes any of the following -

a. an amount allowed by the seller on a trade-in or an exchange of any article;

b. an amount paid to the seller for anything included with or incorporated onto the vehicle; and/or

c. an amount paid to the seller for the preparation of the vehicle for delivery to the purchaser.

\section{'New Vehicle'}

For a new vehicle (which includes a demonstration model that has been used for that purpose for not more than 2 months) that is a motor car, motor wagon or motorcycle, the 'list price' (see definition below), plus the price fixed by the manufacturer, importer or principle distributor as the additional retail selling price in Western Australia for a particular type of transmission fitted to the vehicle (for example, the set fee to upgrade a manual transmission to automatic).

\section{'List Price'}

List price means the price that has been fixed by the manufacturer, importe or principle distributor as the retail selling price of that vehicle in Western Australia.

\section{APPROVED IMMOBILISER}

An approved immobiliser means an immobiliser fitted by the manufacturer or an immobiliser approved under the Vehicle Engine Immobiliser Scheme. For details of approved immobilisers please visit www.transport.wa.gov.au/licensing or contact Driver and Vehicle Services on 131156 .

\section{CERTIFICATION (SECTION D)}

Section 2 - Authorised Representative Certification

I certify that I have complied with the duties of an authorised representative as specified in Section 2 of the Important Information. PERMIT NUMBER (AS SHOWN ON BULK LICENSING NOMINATION)

SIGNATURE OF AUTHORISED REPRESENTATIVE

\section{NAME}

DATE

FOR AND ON BEHALF OF

OFFICIAL STAMP OF DEALERSHIP

\section{DEALER USE ONLY}

CONCESSION CODE

CONCESSION APPLICATION ATTACHED

DEALER CERTIFICATE ATTACHED

POI ATTACHED (WHERE APPLICABLE)

PERIOD OR BLOCK DATE

PLATE NUMBER

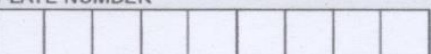


2018 Journal of Australian Taxation - Volume 20 - Art 2 Fullarton

Appendix B

\begin{tabular}{|c|c|c|c|c|c|}
\hline Date & Distance & Odometer & Litres & $\begin{array}{c}\text { Fuel } \\
\text { Consumption } \\
\text { in } \mathrm{L} / 100 \mathrm{~km} \\
\end{array}$ & Trip \\
\hline \multirow[t]{4}{*}{$30 / 05 / 2016$} & 0 & & & & Delivery Per \\
\hline & & & 12.09 & & \\
\hline & & & 28.66 & & \\
\hline & & & 36.93 & & \\
\hline Sub-total & 1088 & 1088 & 77.68 & 7.139706 & per/cvn \\
\hline $4 / 09 / 2016$ & 1449 & 2537 & 23.32 & 1.609386 & $\mathrm{cvn}$ \\
\hline \multirow[t]{5}{*}{$23 / 09 / 2016$} & & & 7.00 & & \\
\hline & & & 32.65 & & \\
\hline & & & 36.4 & & \\
\hline & & & 15.53 & & \\
\hline & & & 30.01 & & \\
\hline Sub-total & 1741 & 4278 & 121.59 & 6.983917 & cvn/per/cvn \\
\hline \multirow[t]{5}{*}{ 13-Oct } & & & 34.69 & & \\
\hline & & & 28.75 & & \\
\hline & & & 35.61 & & \\
\hline & & & 32.09 & & \\
\hline & & & 18.72 & & \\
\hline Sub-total & 2307 & 6585 & 149.86 & 6.495882 & cvn/per/cvn \\
\hline \multirow[t]{2}{*}{ 28-Oct } & & & 13.34 & & \\
\hline & & & 27.01 & & \\
\hline Sub-total & 1012 & 7597 & 40.35 & 3.987154 & cvn/per \\
\hline \multirow[t]{4}{*}{ 16-Nov } & & & 32.08 & & \\
\hline & & & 45.21 & & \\
\hline & & & 13.80 & & \\
\hline & & & 33.27 & & \\
\hline Sub-total & 1565 & 9162 & 124.36 & 7.946326 & per/cvn \\
\hline \multirow[t]{2}{*}{ 19-Nov } & & & 34.00 & & \\
\hline & & & 34.43 & & \\
\hline Sub-total & 1316 & 10478 & 68.43 & 5.199848 & cvn/ger/cvn \\
\hline \multirow[t]{2}{*}{ 19-Dec } & & & 44.35 & & \\
\hline & & & 44.15 & & \\
\hline Sub-total & 1632 & 12110 & 88.5 & 5.422794 & cvn/ger/cvn \\
\hline \multirow[t]{6}{*}{ 25-Jan } & & & 44.35 & & \\
\hline & & & 44.57 & & \\
\hline & & & 38.77 & & \\
\hline & & & 44.58 & & \\
\hline & & & 41.38 & & \\
\hline & 3703 & 15813 & 213.65 & 5.769646 & cvn/per/cvn \\
\hline 26-Mar & & & 38.06 & & \\
\hline
\end{tabular}


2018 Journal of Australian Taxation - Volume 20 - Art 2 Fullarton

\begin{tabular}{|c|r|r|r|r|l|}
\hline & & & 37.23 & & \\
\hline Sub-total & 967 & 16780 & 75.29 & 7.785936 & cvn/ger/cvn \\
\hline 30-Apr & & & 36.55 & & \\
\hline & & & 10.48 & & \\
\hline & & & 44.16 & & \\
\hline Sub-total & 1906 & 18686 & 91.19 & 4.784365 & cvn/ger/cvn \\
\hline 12-Jul & & & 47.04 & & \\
\hline & & & 10.00 & & \\
\hline & & & 46.41 & & \\
\hline & & & 10.01 & & \\
\hline Sub-total & 2194 & 20880 & 113.46 & 5.171376 & cvn/ger/cvn \\
\hline 27-Jul & & & 41.23 & & \\
\hline & & & 27.82 & & \\
\hline & & & 35.36 & & \\
\hline & & & 11.27 & & \\
\hline & & & 30.00 & & \\
\hline Sub-total & 2221 & 23101 & 145.68 & 6.559208 & cvn/kta/cvn \\
\hline 17-Nov & 875 & 23976 & 21.43 & 2.449143 & cvn \\
\hline & & & & & \\
\hline Total & $\mathbf{2 3 9 7 6}$ & $\mathbf{2 3 9 7 6}$ & $\mathbf{1 3 3 3 . 3 6}$ & $\mathbf{5 . 5 6 1 2 2 8}$ & \\
\hline
\end{tabular}




\section{Bibliography}

\section{Articles/Books/Reports}

Arnalich, Santiago, Epanet and Development: How to Calculate Water Networks by Computer (Arnalich, Water and Habitat, 2011).

Australian Government, Department of Industry and Science, Australian Energy Update (2015).

Briggs, David John et al, 'Mapping Urban Air Pollution Using GIS: A Regression-Based Approach' (1997) 11(7) International Journal of Geographical Information Science 699 <http://www.tandfonline.com/doi/abs/10.1080/136588197242158> at 18 February 2018.

Bukhari, Syed Abid Ali Shah et al, 'Future of Microgrids with Distributed Generation and Electric Vehicles' in Wen-Ping Cao and Jin Yang (eds) Development and Integration of Microgrids (2017) 55.

Casals, Lluc Canals et al, 'Sustainability Analysis of the Electric Vehicle Use in Europe for CO2 Emissions Reduction' (2016) 127 Journal of Cleaner Production 425

$<$ https://www.sciencedirect.com/journal/journal-of-cleaner-production/vol/127> at 18

February 2018.

Everett, Robert and Godfrey Boyle, 'Integration' in Godfrey Boyle (ed), Renewable Energy: Power for a Sustainable Future (Oxford University Press, $2^{\text {nd }}$ ed, 2004) 383.

Falcão, Eduardo Aparecido Moreira, Ana Carolina Rodrigues Teixeira and José Ricardo Sodré, 'Analysis of $\mathrm{CO} 2$ Emissions and Techno-economic Feasibility of an Electric Commercial $\begin{array}{lllll}\text { Vehicle' (2017) } & 193 & \text { Applied } & \text { Energy } & 297\end{array}$ <https://www.sciencedirect.com/science/article/pii/S0306261917301794> at 18 February 2018.

Fullarton, Alexander Robert, Watts in the Desert: Pioneering Solar Farming in Australia's Outback (Ibidem Verlag, 2016).

Galvin, Ray, 'Energy Consumption Effects of Speed and Acceleration in Electric Vehicles: Laboratory Case Studies and Implications for Drivers and Policymakers' (2017) 53

Transportation Research Part D 234

<https://www.sciencedirect.com/science/article/pii/S1361920915301280> at 18 February 2018.

Graham-Rowe, Ella et al, 'Mainstream Consumers Driving Plug-In Battery-Electric and Plug-In Hybrid Electric Cars: A Qualitative Analysis of Responses and Evaluations' (2012) 46 Transportation Research Part A 140 <https://www.sciencedirect.com/science/article/pii/S0965856411001418> at 18 February 2018 . 
Jochem, Patrick et al, 'Methods for Forecasting the Market Penetration of Electric Drivetrains in the Passenger Car Market' (2018) 38 Transport Reviews 322

<https://www.tandfonline.com/doi/full/10.1080/01441647.2017.1326538> at 5 March 2018.

Lombardi, Lidia et al, 'Comparative Environmental Assessment of Conventional, Electric, Hybrid, and Fuel Cell Powertrains Based on LCA' (2017) The International Journal of Life Cycle Assessment <https://link.springer.com/article/10.1007/s11367-017-1294-y> at 7

November 2017.

Martin, Stanley Leonard and Andrew Kenneth Connor, Basic Physics 1 (Whitcombe and Tombs Pty Ltd, 1968).

McIntosh, Lauchlan, 'Charging for Road Use' (CEDA Bulletin, October 1998).

Mortimore, Anna, 'Reforming Vehicle Taxes on New Car Purchases Can Reduce Road Transport Emissions_ Ex Post Evidence’ (2014) 29 Australian Tax Forum 177.

Pressman, Matt, 'Electric Car Incentives in Norway, UK, France, Germany, Netherlands, \& Belgium' (2017) CleanTechnica < https://cleantechnica.com/2017/09/02/electric-carincentives-norway-uk-france-germany-netherlands-belgium/> at 19 October 2017.

Schott, Benjamin, Andreas Püttner and Martin Müller, 'The Market for Battery Electric Vehicles' in Bruno Scrosati, Jürgen Garche and Werner Tillmetz (eds) Advances in Battery Technologies for Electric Vehicles (Woodhead Publishing 2015) 35.

Sharma, Nikhil et al, 'Air Pollution and Control' in Avinash Kumar Agarwal and Ashok Pandey (eds) Energy, Environment and Sustainability (Springer, 2017) 3.

Simpson, Genevieve, 'Network Operators and the Transition to Decentralised Electricity: An Australian Socio-technical Case Study’ (2017) 110 Energy Policy 422.

Twidell, John W and Anthony D Weir, Renewable Energy Resources (Taylor and Francis, $2^{\text {nd }}$ ed, 2006).

\section{Case Law}

Dennis Hotels Pty Ltd v Victoria (1959-1960) 104 CLR 529.

Matthews v Chicory Marketing Board (Vic) (1938) 60 CLR 263.

Ngo Ngo Ha and Anor v New South Wales [1996] HCA 17.

\section{Legislation}

Acts Amendment and Repeal (Road Maintenance) 1979 (WA).

Commonwealth Aid Roads Act 1954 (Cth).

Commonwealth Aid Roads Act 1959 (Cth). 
Commonwealth of Australia Constitution Act 1900 (Imp) 63 \& 64 Vict, c 12.

Excise Tariff Act 1921 (Cth).

Excise Tariff Amendment (Fuel Indexation) Act (No 101) 2015 (Cth).

\section{Treaties}

\section{Other Sources}

Australian Bureau of Statistics, 9309.0 - Motor Vehicle Census, Australia, 31 Jan 2016 (2016)

<http://www.abs.gov.au/AUSSTATS/abs@.nsf/DetailsPage/9309.031\%20Jan\%202016?Ope nDocument $>$ at 17 February 2018.

Australian Bureau of Statistics, Consumer Price Index Inflation Calculator (2017)

<http://www.abs.gov.au/websitedbs/d3310114.nsf/home/Consumer+Price+Index+Inflation+ Calculator> at 13 July 2017.

Australian Government, Department of Industry and Science, Australian Energy Update (Office of the Chief Economist, 2015) < https://industry.gov.au/Office-of-the-Chief-

Economist/Publications/Documents/aes/2015-australian-energy-statistics.pdf $>$ at 1 November 2017.

Australian Government, Department of Infrastructure and Regional Development, Bureau of Infrastructure, Transport, and Regional Economics, Key Australian Infrastructure Statistics 2016 <https://bitre.gov.au/publications/2016/files/BITRE_yearbook_2016_pocket_book.pdf> at 13 July 2017.

Australian Government, Australian Tax Office Taxation Statistics 2014-15

$<$ http://data.gov.au/dataset/taxation-statistics-2014-15/resource/37b0b252-7c5a-4895-a708db071c54d5fd?inner_span=True> at 12 July 2017.

Australian Taxation Office, Fuel Schemes/Eligible Activities (2017) $<$ https://www.ato.gov.au/business/fuel-schemes/fuel-tax-credits--business/eligibility/eligible-activities/> at 25 November 2017.

Australian Taxation Office, Research and Statistics; Taxation Statistics (2007) $<$ https://www.ato.gov.au/About-ATO/Research-and-statistics/In-detail/Taxationstatistics/Taxation-Statistics-2004-05/?page=41\#Energy_grant_schemes $>$ at 25 November 2017.

Australian Taxation Office, Organisations/Australian Taxation Office/Taxation Statistics 2014-15/Excise - Table 1 (2017) <http://data.gov.au/dataset/taxation-statistics-201415/resource/37b0b252-7c5a-4895-a708-db071c54d5fd?inner_span=True> at 12 July 2017. 
Bukhari, Syed Abid Ali Shah et al, 'Future of Microgrids with Distributed Generation and Electric Vehicles' in Wen-Ping Cao and Jin Yang (eds) Development and Integration of Microgrids (Intech, 2017) 55

$<$ https://www.intechopen.com/books/howtoreference/development-and-integration-ofmicrogrids/future-of-microgrids-with-distributed-generation-and-electric-vehicles $>$ at 18 February 2018.

Campey, Tom et al, Low Emissions Technology Roadmap (Commonwealth Scientific and Industrial Research Organisation, 2017)

Commonwealth, Parliamentary Debates, Senate, 7 May 1959 (Agnes Robertson, Senator for Western Australia).

Commonwealth, Parliamentary Debates, House of Representatives, 29 April 1959 (Joseph Clark, Member for Darling).

Council of Australian Governments, Intergovernmental Agreement on the Reform of Commonwealth-State Financial Relations - 25 July 1999 (1999)

$<$ https://www.coag.gov.au/sites/default/files/agreements/reform_of_commstate_financial_relations_PDF.pdf $>$ at 18 February 2018.

Crowe, David, 'Electric Cars Blow Hole in Road-Building Petrol Tax Revenues', The Australian (Sydney), 16 August 2016.

Desbarats, Jane, An Analysis of the Obstacles to Inclusion of Road Transport Emissions in the European Union's Emissions Trading Scheme (Institute for European Environmental Policy, 2009) <https://ieep.eu/publications/an-analysis-of-the-obstacles-to-inclusion-of-roadtransport-emissions-in-the-european-union-s> at 29 October 2017.

Du, Guanhao, et al., 'An Optimization Model of EVs Charging and Discharging for Power System Demand Leveling' (Paper presented at the 2016 Institute of Electrical and Electronic Engineers' Power and Energy Society Asia-Pacific Power and Energy Conference, Xi'an, China, 25 October 2016).

Economics, Commerce and Industrial Relations Group, Parliament of Australia, Petrol and Diesel Excises (2000)

<http://www.aph.gov.au/About_Parliament/Parliamentary_Departments/Parliamentary_Libra ry/pubs/rp/rp0001/01RP06\#WhyisExciseLevied> at 16 July 2017.

Email from Karl Gehling (Head of Corporate Communications, Mitsubishi Motors Australia Ltd) to Alexander Robert Fullarton, 10 May 2017.

Fernández, Roberto Álvarez, 'A More Realistic Approach to Electric Vehicle Contribution to Greenhouse Gas Emissions in the City' (2018) 172 Journal of Cleaner Production <https://www.sciencedirect.com/science/article/pii/S0959652617324654> at 16 February 2018.

Ford Motor Company of Australia Limited, 'Explore ESCAPE |Escape Ambiente 1.5L EcoBoost Petrol AWD' <https://www.ford.com.au/suv/escape/models/ambienteawd/?intcmp=vhp-return-model $>$ at 6 November 2017 . 
Fullarton, Alexander Robert, 'The Apparition of Tax Reform: A Paper That Examines the Issue of Taxation Reform in Australia' (November 14, 2003) Social Science Research Network (SSRN) <https://ssrn.com/abstract=3002871> at 20 July 2017.

Graham, Paul W and Alan Smart, Possible Futures: Scenario Modelling of Australian Alternative Transport Fuels to 2050 (Commonwealth Scientific and Industrial Research Organisation, 2011) <https://publications.csiro.au/rpr/home> at 1 November 2017.

Graham, Paul W and Thomas S Brinsmead, Efficient Capacity Utilisation: Transport and Building Services Electrification (Commonwealth Scientific and Industrial Research Organisation, 2016).

Graham, Paul W and Luke J Reedman, Projecting Future Road Transport Revenues 20152050 (Commonwealth Scientific and Industrial Research Organisation, 2015).

Kia Motors Corporation, Sportage (2017)

<http://www.kia.com/au/cars/sportage/specification.html> at 6 November 2017.

Lambert, Frederick, The Dutch Government Confirms Plan to Ban New Petrol and Diesel Cars by 2030 (Electrek, 2017) <https://electrek.co/2017/10/10/netherlands-dutch-ban-petroldiesel-cars-2030-electric-cars/> at 19 October 2017.

Mitsubishi Motors, Outlander AWD Petrol (2017) <https://www.mitsubishimotors.com.au/vehicles/outlander/specifications/outlander-awd-petrol> 6 November 2017.

Mitsubishi Motors, Outlander PHEV (2017)

<https://www.mitsubishi-motors.com.au/vehicles/outlander-phev> at 5 November 2017.

Nissan Motor Co (Australia) Pty Ltd, Nissan Qashqai (2017)

<http://www.nissan.com.au/ /media/Files/Brochures/Specifications/QASHQAI/QASHQAI\% 20Spec\%20Jul\%202015.ashx> at 6 November 2017.

Parliament of Australia, Background Papers, Fuel Taxation Inquiry, History of Fuel Taxation In Australia (2001) 2

<http://fueltaxinquiry.treasury.gov.au/content/backgnd/download/002.pdf> at 30 June 2014.

Parliament of Australia, Parliamentary Business, Fuel Indexation (Road Funding) Bill 2014 and Related Bills (2014)

<https://www.aph.gov.au/Parliamentary_Business/Committees/Senate/Economics/Fuel_Inde xation_2014/Report/c02> at 13 March 2018.

Passey, Robert J, Muriel Emmeline Watt and Iain Macgill, 'The Financial Impacts of PV Systems and Plug-in Hybrid Electric Vehicles on Customers Who Do Not Have Them' (Paper presented at the 2014 Asia-Pacific Solar Research Conference, University of New South Wales, 8 December 2014).

Perera, Frederica P, 'Multiple Threats to Child Health from Fossil Fuel Combustion: Impacts of Air Pollution and Climate Change' (2017) 125(2) Environmental Health Perspectives <https://ehp.niehs.nih.gov/ehp299/> at 16 February 2016. 
Pressman, Matt, Electric Car Incentives in Norway, UK, France, Germany, Netherlands, \& Belgium (CleanTechnica, 2017) <https://cleantechnica.com/2017/09/02/electric-carincentives-norway-uk-france-germany-netherlands-belgium/> at 19 October 2017.

Senate Standing Committee on Economics, Parliament of Australia, Fuel Indexation (Road Funding) Bill 2014 and 3 Related Bills (2014) [2.16]

<https://www.aph.gov.au/Parliamentary_Business/Committees/Senate/Economics/Fuel_Inde xation_2014/Report/c02> at 1 March 2018.

Simpson, Genevieve, 'Network Operators and the Transition to Decentralised Electricity: An Australian Socio-technical Case Study' (2017) 110 Energy Policy 422

$<$ https://www.sciencedirect.com/science/article/pii/S0301421517305463> at 18 February 2018.

Subaru (Australia) Pty Ltd, Subaru Forester (2017)

<https://www.subaru.com.au/forester/performance> at 6 November 2017.

Toyota Motor Corporation Australia Limited, RAV 4, GX 2.0L petrol 5D Wagon (2017) $<$ http://www.toyota.com.au/rav4/specifications/gx-2-01-petrol-5d-wagon-6-manual-2wd> at 6 November 2017.

Webb, Richard, 'Cost Recovery in Road and Rail Transport' (Research Paper No 28, Department of the Parliamentary Library, Parliament of Australia, 1999-2000)

Webb, Richard, Petrol and Diesel Excises (Economics, Commerce and Industrial Relations Group, 2000)

<http://www.aph.gov.au/About_Parliament/Parliamentary_Departments/Parliamentary_Libra ry/pubs/rp/rp0001/01RP06\#WhyisExciseLevied> at 16 July 2017.

World Nuclear Association, Electricity and Cars (2017) <http://www.worldnuclear.org/information-library/energy-and-the-environment/electricity-and-cars.aspx $>$ at 19 October 2017.

Zhou, Yan et al, 'Plug-In Electric Vehicle Market Penetration and Incentives: A Global Review' (2015) 20(5) Mitigation and Adaptation Strategies for Global Change 10-1 <https://link-springer-com.dbgw.lis.curtin.edu.au/article/10.1007/s11027-014-9611-2> at 5 March 2018. 